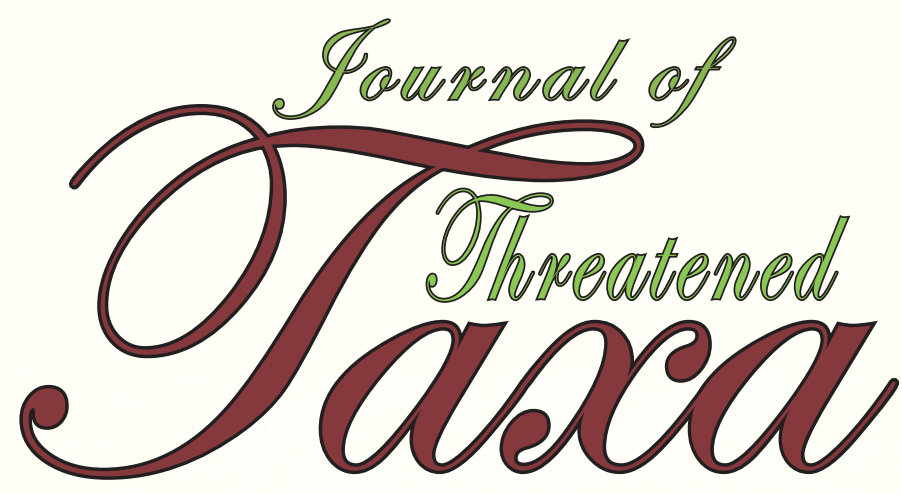

10.11609/jott.2021.13.14.20143-20310 enever.threatenedtaxa.org

26 December 2021 (Online \& Print) Val. 13 | Na. 14 | Pages: 20143-20310 155n 0974-7907 (Online) 155n 0974-7893 (Print)

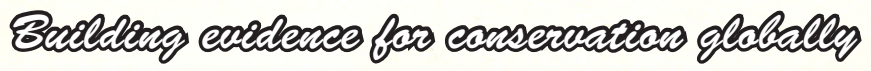

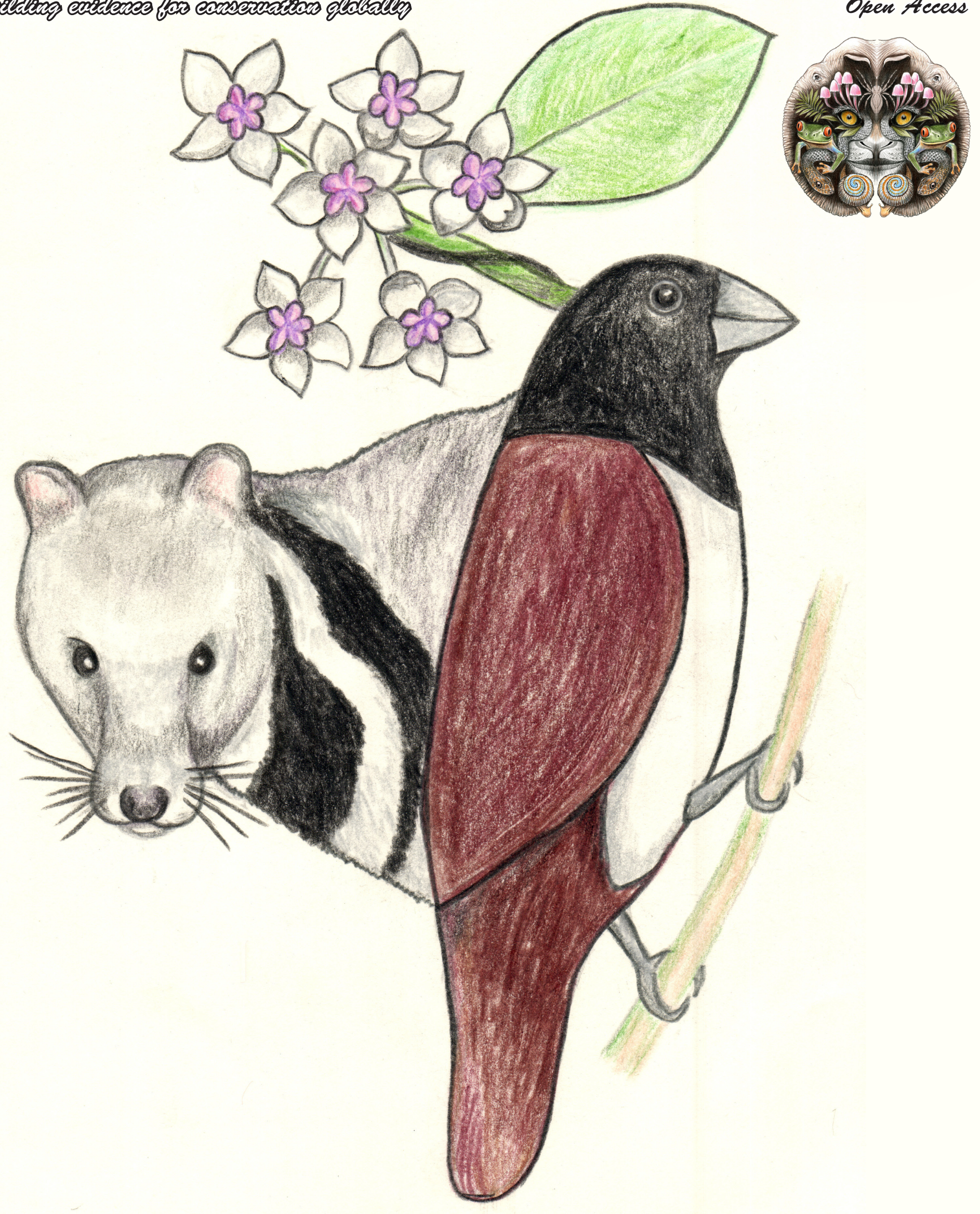

Open Access 


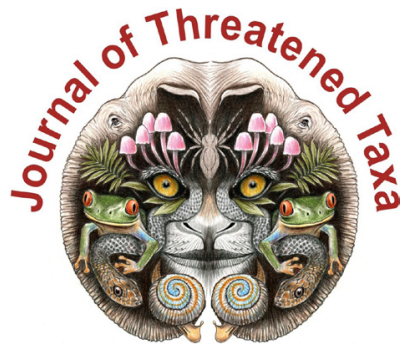

ISSN 0974-7907 (Online); ISSN $0974-7893$ (Print)

Publisher

Host

Wildlife Information Liaison Development Society

www.wild.zooreach.org

Zoo Outreach Organization www.zooreach.org

No. 12, Thiruvannamalai Nagar, Saravanampatti - Kalapatti Road, Saravanampatti, Coimbatore, Tamil Nadu 641035, India

Ph: +91 9385339863 | www.threatenedtaxa.org

Email: sanjay@threatenedtaxa.org

EDITORS

\section{Founder \& Chief Editor}

Dr. Sanjay Molur

Wildlife Information Liaison Development (WILD) Society \& Zoo Outreach Organization (ZOO),

12 Thiruvannamalai Nagar, Saravanampatti, Coimbatore, Tamil Nadu 641035, India

\section{Deputy Chief Editor}

Dr. Neelesh Dahanukar

Noida, Uttar Pradesh, India

\section{Managing Editor}

Mr. B. Ravichandran, WILD/ZOO, Coimbatore, India

\section{Associate Editors}

Dr. Mandar Paingankar, Government Science College Gadchiroli, Maharashtra 442605, India

Dr. Ulrike Streicher, Wildlife Veterinarian, Eugene, Oregon, USA

Ms. Priyanka lyer, ZOO/WILD, Coimbatore, Tamil Nadu 641035, India

Dr. BA. Daniel, $200 / \mathrm{WILD}$, Coimbatore, Tamil Nadu 641035, India

\section{Editorial Board}

Dr. Russel Mittermeie

Executive Vice Chair, Conservation International, Arlington, Virginia 22202, USA

\section{Prof. Mewa Singh Ph.D., FASc, FNA, FNASc, FNAPsy}

Ramanna Fellow and Life-Long Distinguished Professor, Biopsychology Laboratory, and Institute of Excellence, University of Mysore, Mysuru, Karnataka 570006, India; Honorary Professor, Jawaharlal Nehru Centre for Advanced Scientific Research, Bangalore; and Adjunct Professor, National Institute of Advanced Studies, Bangalore

\section{Stephen D. Nash}

Scientific Illustrator, Conservation International, Dept. of Anatomical Sciences, Health Sciences Center, T-8, Room 045, Stony Brook University, Stony Brook, NY 11794-8081, USA

\section{Dr. Fred Pluthero}

Toronto, Canada

\section{Dr. Priya Davidar}

Sigur Nature Trust, Chadapatti, Mavinhalla PO, Nilgiris, Tamil Nadu 643223, India

\section{Dr. Martin Fisher}

Senior Associate Professor, Battcock Centre for Experimental Astrophysics, Cavendish

Laboratory, JJ Thomson Avenue, Cambridge CB3 OHE, UK

\section{Dr. John Fellowes}

Honorary Assistant Professor, The Kadoorie Institute, 8/F, T.T. Tsui Building, The University of Hong Kong, Pokfulam Road, Hong Kong

\section{Prof. Dr. Mirco Solé}

Universidade Estadual de Santa Cruz, Departamento de Ciências Biológicas, Vice-coordenado do Programa de Pós-Graduação em Zoologia, Rodovia Ilhéus/Itabuna, Km 16 (45662-000)

Salobrinho, Ilhéus - Bahia - Brasil

\section{Dr. Rajeev Raghavan}

Professor of Taxonomy, Kerala University of Fisheries \& Ocean Studies, Kochi, Kerala, India

\section{English Editors}

Mrs. Mira Bhojwani, Pune, India

Dr. Fred Pluthero, Toronto, Canad

Mr. P. Ilangovan, Chennai, India

Web Development

Mrs. Latha G. Ravikumar, ZOO/WILD, Coimbatore, India

\section{Typesetting}

Mr. Arul Jagadish, ZOO, Coimbatore, India

Mrs. Radhika, ZOO, Coimbatore, India

Mrs. Geetha, ZOO, Coimbatore India
Fundraising/Communications

Mrs. Payal B. Molur, Coimbatore, India

Subject Editors 2018-2020

Fungi

Dr. B. Shivaraju, Bengaluru, Karnataka, India

Dr. R.K. Verma, Tropical Forest Research Institute, Jabalpur, India

Dr. Vatsavaya S. Raju, Kakatiay University, Warangal, Andhra Pradesh, India

Dr. M. Krishnappa, Jnana Sahyadri, Kuvempu University, Shimoga, Karnataka, India

Dr. K.R. Sridhar, Mangalore University, Mangalagangotri, Mangalore, Karnataka, India

Dr. Gunjan Biswas, Vidyasagar University, Midnapore, West Bengal, India

\section{Plants}

Dr. G.P. Sinha, Botanical Survey of India, Allahabad, India

Dr. N.P. Balakrishnan, Ret. Joint Director, BSI, Coimbatore, India

Dr. Shonil Bhagwat, Open University and University of Oxford, UK

Prof. D.J. Bhat, Retd. Professor, Goa University, Goa, India

Dr. Ferdinando Boero, Università del Salento, Lecce, Italy

Dr. Dale R. Calder, Royal Ontaro Museum, Toronto, Ontario, Canada

Dr. Cleofas Cervancia, Univ. of Philippines Los Baños College Laguna, Philippines

Dr. F.B. Vincent Florens, University of Mauritius, Mauritius

Dr. Merlin Franco, Curtin University, Malaysia

Dr. V. Irudayaraj, St. Xavier's College, Palayamkottai, Tamil Nadu, India

Dr. B.S. Kholia, Botanical Survey of India, Gangtok, Sikkim, India

Dr. Pankaj Kumar, Kadoorie Farm and Botanic Garden Corporation, Hong Kong S.A.R., China

Dr. V. Sampath Kumar, Botanical Survey of India, Howrah, West Bengal, India

Dr. A.J. Solomon Raju, Andhra University, Visakhapatnam, India

Dr. Vijayasankar Raman, University of Mississippi, USA

Dr. B. Ravi Prasad Rao, Sri Krishnadevaraya University, Anantpur, India

Dr. K. Ravikumar, FRLHT, Bengaluru, Karnataka, India

Dr. Aparna Watve, Pune, Maharashtra, India

Dr. Qiang Liu, Xishuangbanna Tropical Botanical Garden, Yunnan, China

Dr. Noor Azhar Mohamed Shazili, Universiti Malaysia Terengganu, Kuala Terengganu, Malaysia

Dr. M.K. Vasudeva Rao, Shiv Ranjani Housing Society, Pune, Maharashtra, India

Prof. A.J. Solomon Raju, Andhra University, Visakhapatnam, India

Dr. Mandar Datar, Agharkar Research Institute, Pune, Maharashtra, India

Dr. M.K. Janarthanam, Goa University, Goa, India

Dr. K. Karthigeyan, Botanical Survey of India, India

Dr. Errol Vela, University of Montpellier, Montpellier, France

Dr. P. Lakshminarasimhan, Botanical Survey of India, Howrah, India

Dr. Larry R. Noblick, Montgomery Botanical Center, Miami, USA

Dr. K. Haridasan, Pallavur, Palakkad District, Kerala, India

Dr. Analinda Manila-Fajard, University of the Philippines Los Banos, Laguna, Philippines

Dr. P.A. Sinu, Central University of Kerala, Kasaragod, Kerala, India

Dr. Afroz Alam, Banasthali Vidyapith (accredited A grade by NAAC), Rajasthan, India

Dr. K.P. Rajesh, Zamorin's Guruvayurappan College, GA College PO, Kozhikode, Kerala, India

Dr. David E. Boufford, Harvard University Herbaria, Cambridge, MA 02138-2020, USA

Dr. Ritesh Kumar Choudhary, Agharkar Research Institute, Pune, Maharashtra, India

Dr. Navendu Page, Wildlife Institute of India, Chandrabani, Dehradun, Uttarakhand, India

\section{Invertebrates}

Dr. R.K. Avasthi, Rohtak University, Haryana, India

Dr. D.B. Bastawade, Maharashtra, India

Dr. Partha Pratim Bhattacharjee, Tripura University, Suryamaninagar, India

Dr. Kailash Chandra, Zoological Survey of India, Jabalpur, Madhya Pradesh, India

Dr. Ansie Dippenaar-Schoeman, University of Pretoria, Queenswood, South Africa

Dr. Rory Dow, National Museum of natural History Naturalis, The Netherlands

Dr. Brian Fisher, California Academy of Sciences, USA

Dr. Richard Gallon, llandudno, North Wales, LL30 1UP

Dr. Hemant V. Ghate, Modern College, Pune, India

Dr. M. Monwar Hossain, Jahangirnagar University, Dhaka, Bangladesh

Mr. Jatishwor Singh Irungbam, Biology Centre CAS, Branišovská, Czech Republic.

Dr. Ian J. Kitching, Natural History Museum, Cromwell Road, UK

Dr. George Mathew, Kerala Forest Research Institute, Peechi, India

For Focus, Scope, Aims, and Policies, visit https://threatenedtaxa.org/index.php/JoTT/aims_scope
For Article Submission Guidelines, visit https://threatenedtaxa.org/index.php/JoTT/about/submissions
For Policies against Scientific Misconduct, visit https://threatenedtaxa.org/index.php/JoTT/policies_various 


\title{
Ichthyofaunal diversity with relation to environmental variables in the snow-fed Tamor River of eastern Nepal
}

\author{
Jawan Tumbahangfe ${ }^{1}(\mathbb{D})$, Jash Hang Limbu ${ }^{2}$ (D), Archana Prasad ${ }^{3}(\mathbb{D})$, Bhrarat Raj Subba ${ }^{4}$ (D) \\ \& Dil Kumar Limbu ${ }^{5}(\mathbb{D}$ \\ ${ }^{1,3}$ Central Department of Zoology, Tribhuvan University, Kirtipur Kathmandu Nepal. \\ ${ }^{2,5}$ Central Campus of Technology, Department of Biology, Tribhuvan University, Dharan, Nepal. \\ ${ }^{2,4}$ Nature Conservation and Health Care Council (NCHCC), Biratnagar, Nepal. \\ ${ }^{1}$ jawansubba37@gmail.com, ${ }^{2}$ limbujash@gmail.com (corresponding author), ${ }^{3}$ archanaprasad001@gmail.com, \\ ${ }^{4}$ subbabharatraj@gmail.com, ${ }^{5}$ dilklimbu@gmail.com
}

\begin{abstract}
Tamor River in eastern Nepal supports diverse hill stream fishes. From winter, spring, summer, and autumn of 2020, we investigated the ichthyofaunal diversity with environmental variables in the snow-fed Tamor River covering four seasons (winter, spring, summer, and autumn) and field surveys were carried out in January, April, July, and October 2020. We used two cast nets of different sizes, one with a mesh size of $2 \mathrm{~cm}, 6 \mathrm{~m}$ diameter and $6 \mathrm{~kg}$ weight and another having $0.5 \mathrm{~cm}, 3 \mathrm{~m}$ diameter and $2 \mathrm{~kg}$ weight. In addition, monofilament gill nets with mesh sizes of 6,8 , and 10 were used for fish sampling. A total of 6,373 fish individuals representing 28 species belonging to three orders, seven families, and 16 genera were recorded. One-way permutational multivariate analysis of variance (perMANOVA) on the Non-metric Multidimensional Scaling (NMDS) showed no significant $(P>0.05)$ difference between winter, spring, and autumn season but summer season showed significant $(P<0.05)$ difference from winter, spring, and autumn seasons. Furthermore, one-way analysis of variance on redundancy analysis (RDA) vindicated that among the selected parameters, $\mathrm{pH}$, air temperature and total hardness were the influencing factors $(P<0.05)$ to determine the fish community structure in Tamor River.
\end{abstract}

Keywords: Field survey, fish diversity, hill-stream, multivariate, spatio-temporal.

Citation: Tumbahangfe, J., J.H. Limbu, A. Prasad, B.R. Subba \& D.K. Liimbu (2021). Ichthyofaunal diversity with relation to environmental variables in the snow-fed Tamor River of eastern Nepal. Journal of Threatened Taxa 13(14): 20190-20200. https://doi.org/10.11609/jott.7554.13.14.20190-20200

Copyright: (c) Tumbahangfe et al. 2021. Creative Commons Attribution 4.0 International License. JoTT allows unrestricted use, reproduction, and distribution of this article in any medium by providing adequate credit to the author(s) and the source of publication.

Funding: This study has not received any specific funding.

Competing interests: The authors declare no competing interests.

Author details: JAWAN TUMBAHANGFE is a PhD student at Tribhuvan University's Central Department of Zoology in Kirtipur, Kathmandu, Nepal, with research interests in reproductive biology, molecular biology, stream ecology, and water quality indicators. JASH HANG LIMBU is a program coordinator for the Nature Conservation and Health Care Council (NCHCC) and works at the Central Campus of Technology, Department of Biology, Tribhuvan University, Hattisar, Sunsari district, Dharan, Nepal. Molecular taxonomy, phylogeny, molecular ecology, and conservation ecology are among his study interests. ARCHANA PRASAD's research interests include herbal pesticide, malathion and drug effect on the tissue at cellular level and subcellular level. BHARAT RAJ SUBBA's research interest's include ichthyology and ornithology. DIL KUMAR LIMBU's research interests include Himalayan Rangeland ecology.

Author contributions: JT, JHL and DKL performed field surveys, collected data and prepared the manuscript. AP and BRS supervised the research and provided inputs on manuscript preparation. JHL analyzed the data.

Acknowledgements: The authors express sincere gratitude to Prof. Dr. Tej Bahadur Thapa, HOD, Central Department of Zoology (CDZ), Tribhuvan University for his continuous suggestions and inspiration. We are thankful to Post Graduate Campus, Biratnagar for providing laboratory facilities. We are also thankful to Ms. Jyoti Karna, Ms. Kesika Shrestha, Mr. Ram Bahadur Shrestha, and Mr. Man Kumar Shrestha for their valuable help during field visits. We are thankful to Mr. Asmit Limbu for mapping. 


\section{INTRODUCTION}

Fish community structure, which is regionally diverse and seasonally varied, is often influenced by many environmental variables, as well as biotic interactions like competition and predation (Gorman 1988; Harvey \& Stewart 1991; Grossmann et al. 1998; Frelat et al. 2018; He et al. 2020). Habitat variables such as water temperature, depth (Kadye et al. 2008; Hossain et al. 2012; Li et al. 2012), water velocity (Yu \& Lee 2002; Arvendo \& Ramirez 2017; Limbu et al. 2019), stream width (Gerhard et al. 2004), substrate, altitude, conductivity (Yu \& Lee 2002; Kadye et al. 2008; Yan et al. 2010), dissolved oxygen, $\mathrm{pH}$, free-carbon dioxide (Limbu et al. 2019; Prasad et al. 2020) and climate (Magalhaes et al. 2002) have all been shown to affect fish assemblages. However, changing environmental parameters can affect biotic communities in multiple ways and influence the function of ecosystems (McGill et al. 2006; Conversi et al. 2015). Environmental variables are reported to shape the spatial distribution of species (Perry et al. 2005; Vieira \& Garro 2020) and influence the temporal variation of communities (Rouyer et al. 2008; Vieira \& Garro 2020).

The spatial and temporal variations of the fish community structure in rivers and streams of eastern Nepal are poorly understood (Limbu et al. 2019; Adhikari et al. 2021). However, some of the important studies done in eastern Nepal's rivers and streams include (Shrestha 2009; Shrestha 2016; Shah 2016; Subba et al. 2017; Limbu \& Prasad 2017, 2020; Limbu et al. $2018,2019,2020)$. Some outlook of the fisheries and fish ecological studies such as their diversity, spatial \& seasonal distribution, and plenty in rivers of Nepal are needed (Mishra \& Baniya 2017). To better understand, manage, and conserve (Ngor et al. 2018), and also to know the status (Limbu et al. 2019) of the fisheries, there is an urgent need to update the information on the spatial and temporal fish diversity, community structure and distribution patterns (Ngor et al. 2018).

Thus, the present study aimed to understand relationships among spatio-temporal variation in fish and environmental variables of Tamor River, to reduce the gap in the information and hence dilate the fish diversity profile of Nepal. The present study hypothesized that fish numbers in the Tamor River would be greater during the annual dry season when water current and volume are reduced. We also hypothesized that fish assemblage structure would vary between seasonal variation defined by environmental variables.

\section{MATERIALS AND METHODS}

\section{Study area}

Tamor River lies in eastern Nepal, which begins around Kanchenjunga. The Tamor and the Arun join the Sunkoshi at Tribeni Ghat to form the giant SaptaKoshi which flows through Mahabharat range (Shrestha 2009). It lies in the latitude and longitude co-ordinates of $26.913^{\circ} \mathrm{N}$ and $87.157^{\circ} \mathrm{E}$ respectively. The total length of this river is about $190 \mathrm{~km}$ with 5,817 km catchment area (Shrestha et al. 2009). The study area has connections with four districts, i.e., Taplejung, Panchthar, Terathum, and Dhankuta. Boulders, pebbles, sand, and gravels were the major characteristic features of this river.

\section{Data collection, Identification and Preservation}

Fish sampling was done in winter, spring, summer, and autumn (January, April, July, and October) of 2020. It started on the $15^{\text {th }}$ and continued to the $30^{\text {th }}$ of the selected months. We made 28 samples at seven stations, namely, (SA) Kabeli Dovan, (SB) Hewa Dovan, (SC) Nawa Khola Dovan, (SD) Chharuwa Dovan, (SE) Yakchana Ghat, (SF) Mulghat, and (SG) Triveni with fish sampling carried out between 0700 and $1100 \mathrm{~h}$. We used two cast nets of different sizes, one with mesh size of $2 \mathrm{~cm}, 6 \mathrm{~m}$ diameter, and $6 \mathrm{~kg}$ weight and another with $0.5 \mathrm{~cm}$ mesh size, 3 $\mathrm{m}$ diameter, and $2 \mathrm{~kg}$ weight. Cast netting was carried out covering 150-200 m (Limbu et al. 2021) across each station and all possible habitats were covered. In addition, monofilament gill nets with mesh sizes of 6,8 , and 10 were used to capture the fish. In each station, nine gill nets were left late in the evening (1700-1800 h) and taken out early in the morning (0600-0700 h) in a sampling distance of 150-200 m.

The collected fish were photographed in a fresh condition and identified in the field and if not, then the voucher specimens were preserved in $10 \%$ formalin. After the photography, the remaining samples were returned to their own natural habitat from where they were captured. Fishes were identified with the help of standard literature (Talwar \& Jhingran 1991; Jayaram 2010; Shrestha 2019) and other available standard literature. The environmental variables were examined during field visit following the standard methods of American Public Health Association (APHA 2012). Water temperature, dissolved Oxygen (DO), $\mathrm{pH}$, total hardness, water velocity, conductivity, alkalinity, and free carbondioxide (CO). Water temperature $\left({ }^{\circ} \mathrm{C}\right)$ was measured with a digital thermometer by placing it in the water at a depth of $0.3 \mathrm{~m}$. DO ( $\mathrm{mg} / \mathrm{l})$ was measured by the Winkler titrimetric method. $\mathrm{pH}$ was measured using a $\mathrm{pH}$ meter 


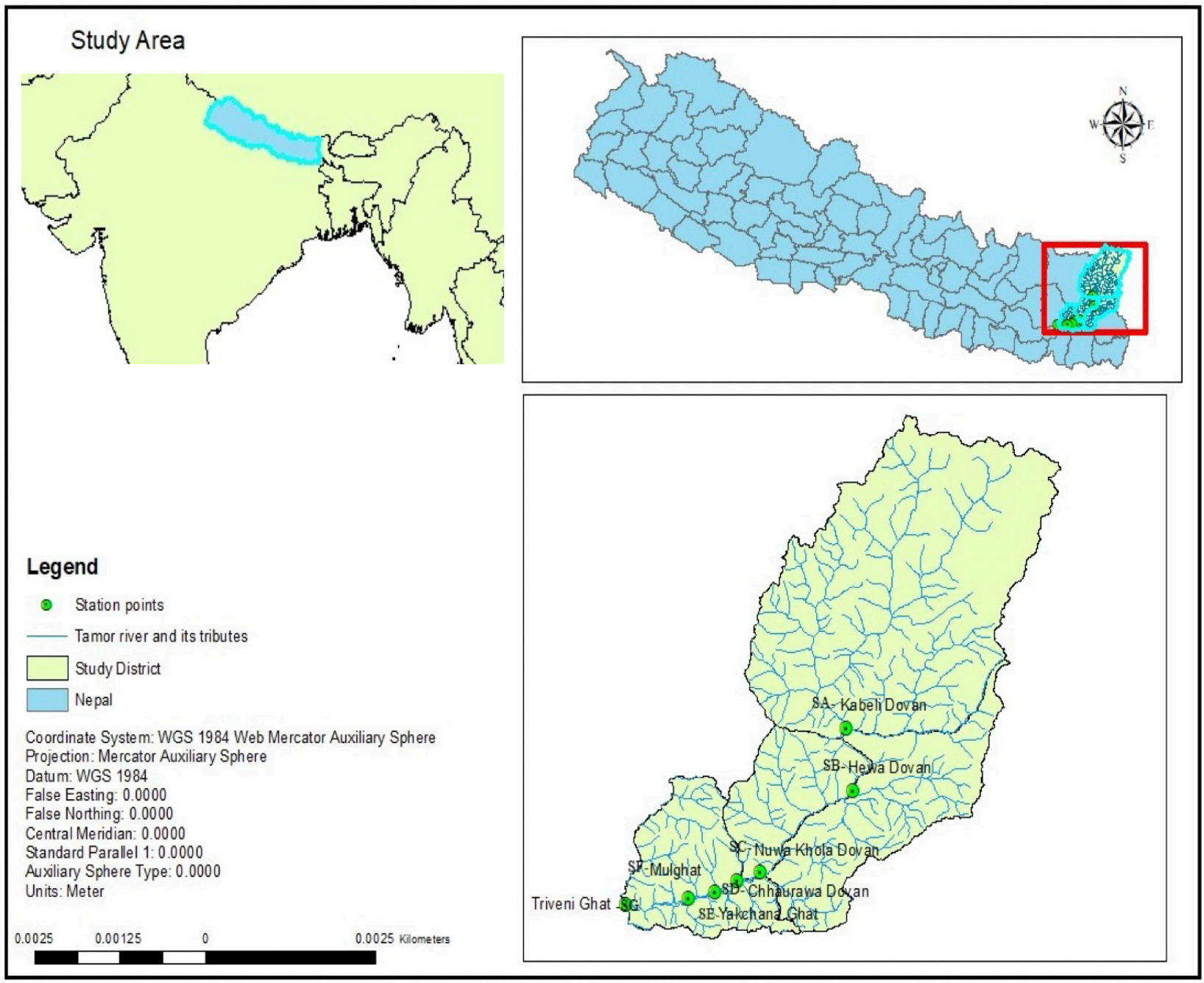

Figure 1. Location of map of study sites in Tamor River, eastern Nepal [SA-Kabeli Dovan; SB - Hewa Dovan; SC - Nuwa Khola Dovan; SD Chhaurawa Dovan: SE - Yakchana Ghat; SF - Mulghat; SG - Triveni Ghat ]

(HI 98107, HANNA Instrument). Total hardness (mg/l) was determined using EDTA titrimetric method. Water velocity $(\mathrm{m} / \mathrm{s})$ was measured by the float method with the help of a stop watch, small ball and measuring tape. Titration method was used to measure the alkalinity $(\mathrm{mg} / \mathrm{l})$. Free carbon dioxide $(\mathrm{mg} / \mathrm{l})$ was measured by the titrimetric method using phenolphthalein as an indicator.

\section{Data analysis}

One-way analysis of variance (ANOVA) was used for temperature, $\mathrm{pH}$, dissolved oxygen, hardness and water velocity to calculate the existence of any differences between space and time spectrum. A post-hoc Tukey HSD test was used to test which means were significantly different at a 0.05 level of probability (Spjøtvoll \& Stoline 1973). The diversity of the fish assemblage was quantified in the first step of data processing, and then statistical comparison was performed (Appendix I). Fish abundance data were subjected to various diversity indices (Shannon, Simpson, an evenness). All three diversity indices were generated using data from the four seasons (in each season seven samples were made, SA-SG) and seven stations (in each station four samples were made, winter, spring, summer, and autumn), and were used directly in the analysis (Yan et al. 2010) for each fish community sample according to Magurran (1988). Shannon diversity index (Shannon \& Weaver 1963) considers both the number of species and the distribution of individuals among species. The Shannon diversity was calculated by following formula:

$$
\mathrm{H}=\sum_{i=1}^{s} P i * \log P i
$$

where $\mathrm{S}$ is the total number of species and $P i$ is the relative cover of $i_{t h}$ of species. 
The dominance index (Harper 1999) was calculated by using following formula:

$$
D=\sum_{i}\left(\frac{n i}{n}\right) 2
$$

where $n$ is number of individuals of species $i$.

Evenness index (Pieleu 1966) was determined by the following equation:

$\mathrm{E}=\mathrm{H}^{\prime} / \log \mathrm{S}$

where, $\mathrm{H}^{\prime}=$ Shannon-Weiner diversity index

$\mathrm{S}=$ Total number of species in the sample.

All of the sample (28) was used in the multivariate analysis, and no species or environmental variables were excluded (Appendix I \& II). Collected fish abundance and determined environmental variables were used directly in the multivariate analysis (Yan et al. 2010; Hossain et al. 2012; Vieira et al. 2020)

One-way permutational multivariate analysis of variance (perMANOVA) (Clarke 1993) was used to test the significant difference among the spatial and temporal scales of the collected fish data. To visualize the major contributing species both to space and time, similarity percentage (SIMPER) (Clarke 1993) analysis was performed.

Detrended correspondence analysis (DCA) (Hill \& Gouch 1983) was used to investigate the relationship between fish community structure and environmental variables. The eigen value (0.13) and axis length (1.17) obtained from DCA suggested that the linear model associated with RDA was more applicable. Therefore, a direct multivariate ordination method (Legendre \& Legendrem 1998) based on a linear response of species to environmental gradients was applied. In addition, using non-metric multi-dimensional scaling analysis (NMDS), the relationships between assemblages from each station and seasons are graphically depicted (Clarke \& Warwick 2001).

\section{RESULTS AND DISCUSSION}

\section{Fish Community structure}

A total of 6,373 fish individuals representing 28 species belonged to three orders, seven families, and 16 genera were recorded during the investigation period (Table 1). Among these, Cypriniformes comprise most of the species with $78.57 \%$, followed by Siluriformes $17.86 \%$, and Anguilliformes with $3.57 \%$. Cyprnidae was the most abundant family which contributed $46.14 \%$, followed by Sisoridae 18\%, Cobitidae 10.7\%, Danionidae 10.7\%, Botiidae 7.14\%, Anguillidae 3.5\%,
Table 1. List of fish collected from Tamor River.

\begin{tabular}{|c|c|c|c|}
\hline Order & Family & Code & Species \\
\hline Cypriniformes & \multirow{3}{*}{ Danionidae } & C3 & Barilius barila Hamilton, 1822 \\
\hline & & C4 & $\begin{array}{l}\text { Opsarius bendelisis Hamilton, } \\
1822\end{array}$ \\
\hline & & C5 & Opsarius shacra Hamilton, 1822 \\
\hline & \multirow{13}{*}{ Cyprinidae } & C8 & Tarquilabeo latius Hamilton, 1822 \\
\hline & & C9 & Culpisoma garua Hamilton, 1822 \\
\hline & & C10 & Gara annandeli Hora, 1921 \\
\hline & & C11 & Garra gotyla Gray, 1830 \\
\hline & & C15 & Labeo angra Hamilton, 1822 \\
\hline & & C16 & $\begin{array}{l}\text { Bangano dero Hamilton- } \\
\text { Buchanan, } 1822 \\
\end{array}$ \\
\hline & & C17 & $\begin{array}{l}\text { Labeo gonius Hamilton-Buchanan, } \\
1822\end{array}$ \\
\hline & & C18 & $\begin{array}{l}\text { Neolissochilus hexagonolepis } \\
\text { McClelland, } 1839\end{array}$ \\
\hline & & C24 & $\begin{array}{l}\text { Schizothorax labitus McClelland, } \\
1839\end{array}$ \\
\hline & & $\mathrm{C} 25$ & $\begin{array}{l}\text { Schizothorax progastus } \\
\text { McClelland, } 1839\end{array}$ \\
\hline & & $\mathrm{C} 26$ & $\begin{array}{l}\text { Schizothorax richardsonii Gray, } \\
1832\end{array}$ \\
\hline & & $\mathrm{C} 27$ & Tor putitora Hamilton, 1822 \\
\hline & & C28 & Tor tor Hamilton, 1839 \\
\hline & Psilorhynchidae & C20 & $\begin{array}{l}\text { Psilorhynchus pseudecheneis } \\
\text { Menon \& Datta, } 1964\end{array}$ \\
\hline & \multirow{2}{*}{ Botiidae } & C6 & Botia almorhae Gray, 1831 \\
\hline & & $\mathrm{C7}$ & Botia lohachata Chaudhauri, 1912 \\
\hline & \multirow{3}{*}{ Cobitidae } & $\mathrm{C} 21$ & Schistura beavani Gunther, 1868 \\
\hline & & $\mathrm{C} 22$ & Schistura horai Menon, 1952 \\
\hline & & $\mathrm{C} 23$ & $\begin{array}{l}\text { Schistura savona Hamilton- } \\
\text { Buchanan, } 1822\end{array}$ \\
\hline \multirow{5}{*}{ Siluriformes } & \multirow{5}{*}{ Sisoridae } & $\mathrm{C} 2$ & $\begin{array}{l}\text { Bagarius bagarius Hamilton- } \\
\text { Buchanan, } 1822\end{array}$ \\
\hline & & $\mathrm{C} 12$ & $\begin{array}{l}\text { Glyptothorax cavia Hamilton- } \\
\text { Buchanan, } 1822\end{array}$ \\
\hline & & $\mathrm{C} 13$ & $\begin{array}{l}\text { Glyptothorax telchitta Hamilton- } \\
\text { Buchanan, } 1822 \\
\end{array}$ \\
\hline & & $\mathrm{C} 14$ & $\begin{array}{l}\text { Glyptothorax pectinopterus } \\
\text { McClelland, } 1842\end{array}$ \\
\hline & & C14 & $\begin{array}{l}\text { Pseudecheneis sulcatus } \\
\text { McClelland, } 1842\end{array}$ \\
\hline Anguilliformes & Anguillidae & $\mathrm{C} 1$ & Anguilla bengalensis Gray, 1832 \\
\hline
\end{tabular}

and Psilorhynchidae 3.5\% (Figure 2). The Cyprinidae was the most species rich family (13 species), followed by Sisoridae (5 species), Danionidae (3 species), Cobitidae (3 species), Botiidae (2 species), Psilorhynchidae and Anguillidae with single species. An environmental impact assessment (EIA) study for the Tamor Hydropower Project has reported the presence of 19 fish species in Tamor River (Swar \& Shrestha 1998) while EIA study of Kabeli Hydropower Project has reported the presence of 21 fish species (Swar \& Upadhaya 1998) and fish 
diversity study reported 30 species in Tamor River (Shrestha 2009). The diversity in terms of number (28 species) observed in the present study was nine species greater than Swar \& Shrestha (1998), seven species greater than Swar \& Upadhaya (1998). It's possible that this is due to the preceding report's limited scope of research. Furthermore, the species diversity may be influenced by fishing gear selectivity and survey efforts. As a result, the current investigation identified a greater number of fish species. But the present study reported two species lower than Shrestha et al. (2009). It might be due to riparian loss, deforestation, river corridor engineering, dams and water diversion, aquatic habitat loss and fragmentation (Dudgeon et al. 2006; Limbu et al. 2021). Ongoing road development, microhydropower generation, poisonous herbicide use, illegal electro-fishing, deforestation, and water diversion are all found to be major threats to the current fish species of Nepal's hillside rivers and streams, according to Limbu et al. (2021) and Adhikari et al. (2021).

Garra nasuta, Botia Dario, Schistura rupecula, Schistura multifaciata, and Pseudecheneis crossicauda, according to local fishermen, have suffered a serious drop in population and are not detected in our collection. The most abundant and species-rich order and family, respectively, were Cypriniformes and Cyprinidae. This is in line with the results of previous studies conducted in Nepal's various rivers and streams. For instance, Subba et al. (2017), Limbu et al. (2018, 2019, 2020), GC \& Limbu (2020), Limbu \& Prasad (2020), Prasad et al. (2020, 2021a,b), Chaudhary et al. (2020) from Tamor, Triyuga, Dewmai, Melamchi, Morang district, Damak, Ratuwa, eastern Nepal, Nuwa Babai River, River Andhi Khola, Seti Gandaki, West Rapti and Betani River. Nelson (2007) also stated that the majority of the fish in the river belong to the Cypriniformes order, which includes 2,422 species of freshwater fish.

Results from the similarity percentage analysis (SIMPER), 64.53\% similarity were found among the seasons and major contributing species were Labeo gonius (9.72\%), Labeo angra (8.46\%), Schizothorax richardsonii (5.92\%), Opsarius shacra (5.87\%), Garra gotyla (5.55\%), Pseudecheneis sulcata (5.48\%), Labeo dero (5.36\%), and Botia lohachata (5.30\%). On the contrary, $50.33 \%$ similarity were found among the sites and major contributing species were Labeo gonius (7.54\%), Labeo angra (6.69\%), Schizothorax richardsonii (5.35\%), Psilorhynchus pseudecheneis (5.30\%), and Pseudecheneis sulcata (5.09\%) (Table 2).

The present study reported two mahseer fishes (Tor spp.) representing an iconic genus of large-bodied

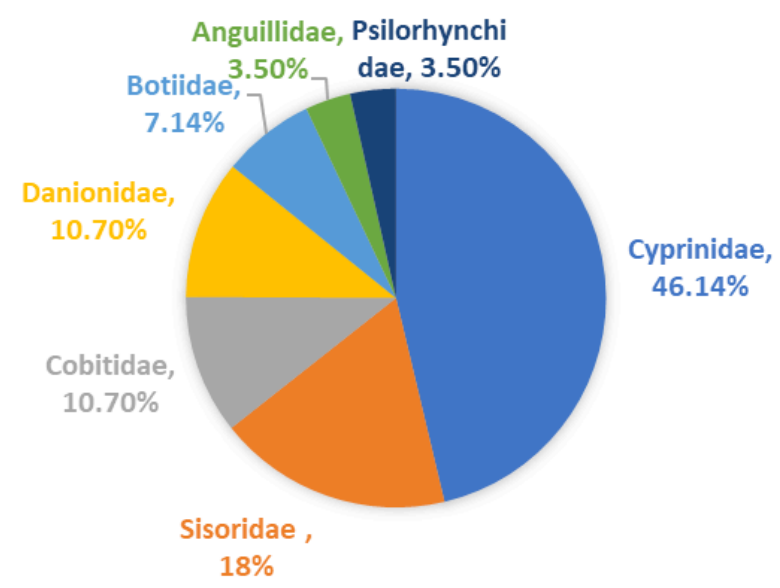

Figure 2. Family wise percentage composition.

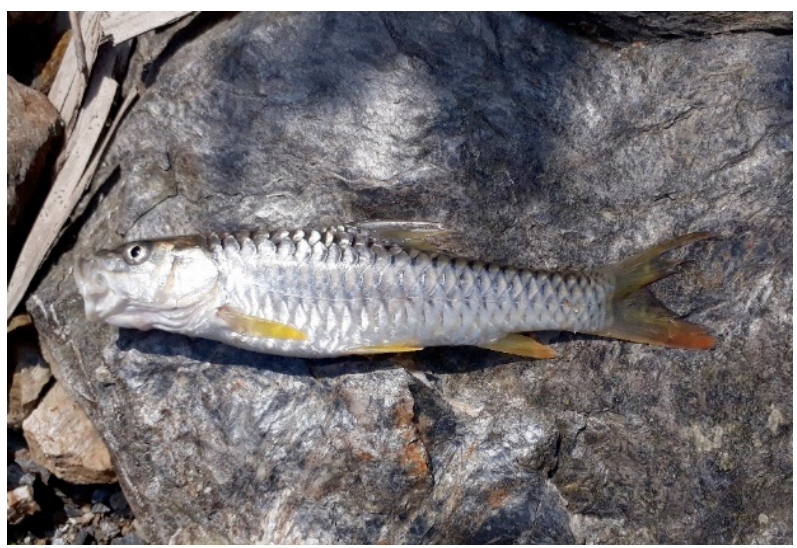

Image 1. Tor putitora

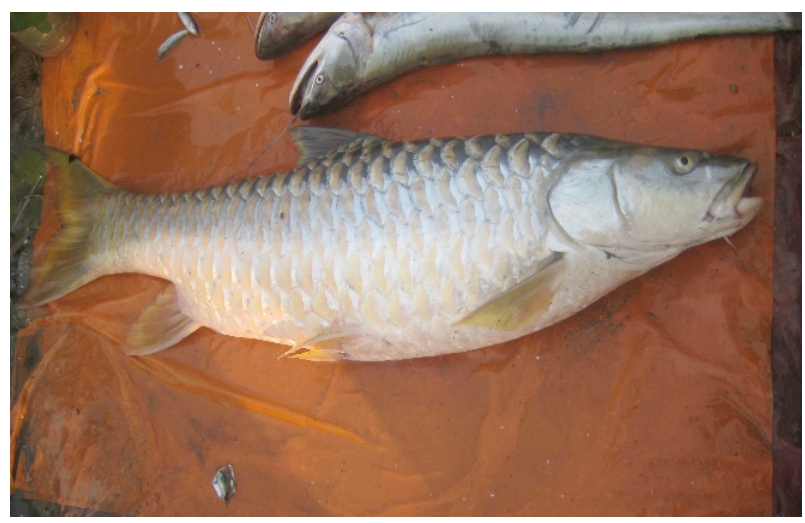

Image 2. Tot tor

species of the Cyprinidae family. Throughout southern and southeastern Asia, these species are revered for their religious and cultural significance (Pinder et al. 2019). Despite their economic and cultural importance, Tor fishes have seen their riverine habitats damaged 
Table 2. Average similarity and discriminating fish in each season and station using SIMPER analysis.

\begin{tabular}{|c|c|c|c|}
\hline Season $(64.53 \%)$ & Contribution & Stations $(50.33 \%)$ & Contribution \\
\hline Contributory species & $\%$ & Contributory species & $\%$ \\
\hline Labeo gonius & 9.72 & Labeo gonius & 7.54 \\
\hline Labeo angra & 8.46 & Labeo angra & 6.69 \\
\hline Schizothorax richardsonii & 5.92 & Schizothorax richardsonii & 5.35 \\
\hline Opsarius shacra & 5.87 & Psilirhynchus pseudecheneis & 5.30 \\
\hline Gara gotyla & 5.55 & Pseudecheneis sulcata & 5.09 \\
\hline Pseudecheneis sulcate & 5.48 & Neolissochilus hexagonolepis & 4.98 \\
\hline Bangano dero & 5.36 & Opsarius shacra & 4.98 \\
\hline Botia lohachatta & 5.30 & Gara gotyla & 4.95 \\
\hline Glyptothorax pectinopterus & 4.70 & Glyptothorax telchitta & 4.78 \\
\hline Glyptothorax telchitta & 4.51 & Labeo dero & 4.48 \\
\hline Barilius barila & 4.13 & Botia lohachata & 4.47 \\
\hline Tarquilabeo latius & 4.01 & Schizothorax progastus & 4.26 \\
\hline Psilorhynchus pseudecheneis & 3.64 & Gara annandalei & 4.24 \\
\hline Schistura savana & 3.51 & Glyptothorax pectinopterus & 4.00 \\
\hline Tor tor & 3.18 & Schistura savana & 3.57 \\
\hline Schizothorax progastus & 3.05 & Barilius barila & 3.55 \\
\hline Neolissochilus hexagonolepis & 3.00 & Opsarius bendelisis & 3.5 \\
\hline Gara annandalei & 3.00 & Botia almorhae & 3.49 \\
\hline Opsarius bendelisis & 2.88 & Tarquilabeo latius & 3.33 \\
\hline Botia almorhae & 2.53 & Glyptothorax cavia & 3.3 \\
\hline Schistura horai & 2.12 & Tor tor & 2.5 \\
\hline Glyptothorax cavia & 1.97 & Schistura horai & 2.01 \\
\hline
\end{tabular}

by anthropogenic activities such as hydroelectric dam construction and exploitation, putting their survival in jeopardy. Furthermore, conservation attempts have been hampered by the fact that the genus' expertise is primarily bent toward aquaculture with significant knowledge gaps on their taphonomy (Bhatt \& Pandit 2016; Pinder et al. 2019). The IUCN Red List has classified Tor putitora as an 'Endangered' species, whereas Tor tor has been classified as 'Data Deficient' (Image 1, 2). Urbanization, poaching, overfishing, and ecological changes in the natural environment's physical, chemical, and biological qualities, according to local fishermen and consent authority, have severely reduced the population of these species in their native habitat. As a result, the conservation of these species is critical.

\section{Diversity status}

The Shannon diversity index considers the richness and proportion of each species, while the Evenness and Dominance indices represent the sample's relative number of individuals and the proportion of common species, respectively (Hossain et al. 2012). Highest Shannon diversity index (2.88) was found at station SB and in summer (3.01) whereas lowest (2.63) was found at SE and in winter (2.56). In contrast, highest Simpson dominance index value was observed at station SA, SB, and SC $(0.932,0.93,0.93)$ and in summer $(0.94)$ whereas lowest value was observed at, SG (0.908) and in winter (0.90). Similarly, highest value of evenness index was observed at SB (0.69) and in summer (0.65) whereas lowest value of evenness index was observed at SG and in winter (0.62) (Table 4 \& 5). According to Hossain et al. (2012), a high Shannon diversity index is associated with a small number of individuals, whereas a low Shannon diversity index is associated with a large number of individuals. A biodiversity index attempts to classify the diversity of a sample (Magurran 1988) and is easily affected by the number of specimens, sampling size, and ecological factors (Leonard et al. 2006).

Fish community structure vs. environmental variables

The result obtained after the redundancy analysis 


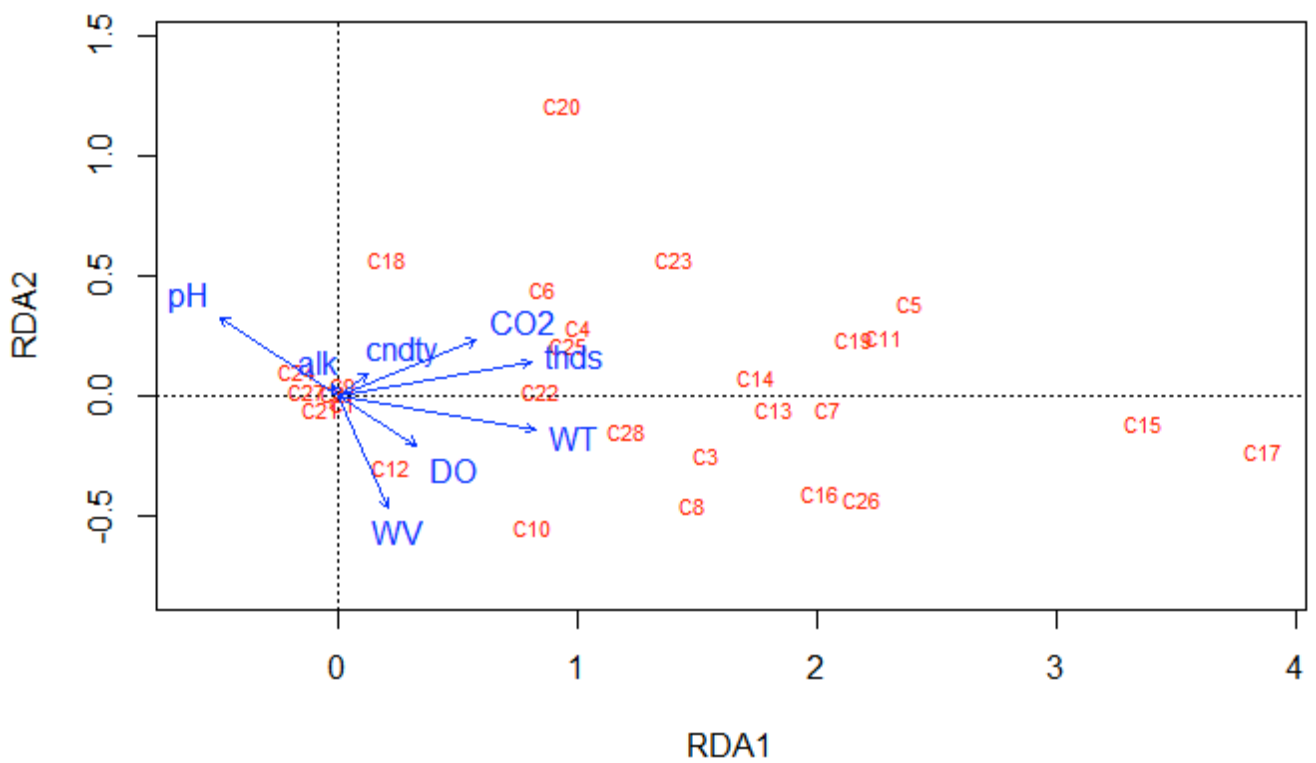

Figure 3. Redundancy analysis (RDA) ordination between fish community structure and environmental variables (for species code refer table 1). thds - total hardness, do dissolved oxygen | WT-water temperature | WV-water velocity | cndty-conductivity | alk-alkalinity | DOdissolved oxygen | $\mathrm{CO}_{2}$-free carbon-dioxide.

Table 4. Station-wise fish faunal diversity indices in the snow-fed Tamor River, Nepal.

\begin{tabular}{|l|c|c|c|}
\hline Station & Shannon Weiner index (H) & Simpson index (D) & Evenness index (E) \\
\hline SA- Kabeli Dovan & $2.82 \pm 0.15$ & $0.932 \pm 0.012$ & $0.64 \pm 0.008$ \\
\hline SB Hewa Dovan & $2.88 \pm 0.13$ & $0.93 \pm 0.012$ & $0.646 \pm 0.008$ \\
\hline SC- Nuwa Khola Dovan & $2.87 \pm 0.126$ & $0.93 \pm 0.01$ & $0.64 \pm 0.0075$ \\
\hline SD- Chhaurawa Dovan & $2.66 \pm 0.25$ & $0.91 \pm 0.026$ & $0.63 \pm 0.018$ \\
\hline SE- Yakchana Ghat & $2.63 \pm 0.307$ & $0.91 \pm 0.031$ & $0.63 \pm 0.022$ \\
\hline SF- Mulghat & $2.74 \pm 0.209$ & $0.924 \pm 0.018$ & $0.63 \pm 0.012$ \\
\hline SG- Triveni Ghat & $2.66 \pm 0.29$ & $0.908 \pm 0.038$ & $0.62 \pm 0.026$ \\
\hline
\end{tabular}

(RDA) was plotted in Figure 3. The first and second axis of the RDA accounted for $76 \%$ and $5.6 \%$, respectively. The fish species of Glyptothorax cavia (C12), Garra annandalei (C10), Tor tor (C28), Tarquilabeo latius (C8), Barilius barila (C3), Glyptothorax pectinopterus (C13), Botia lohachata (C7), Bangana dero (C16), Schizothorax richardsonii (C26), Labeo angra (C15), and Labeo gonius (C17) are positively related to water velocity, dissolved oxygen and water temperature but negatively related to $\mathrm{pH}$ and alkalinity. Fish species of Bagarius bagarius (C2) and Schizothorax labiatus (C24) are positively related to $\mathrm{pH}$ and alkalinity but negatively related to water velocity, $\mathrm{DO}$, and water temperature. In contrast, species of Anguilla bengalensis (C1), Neolissochilus hexagonolepis (C18), Botia almorhae (C6), Barilius bendelisis (C4), Schizothorax progastus (C25), Schistura horai (C22), Glyptothorax telchitta (C14), Schistura savana (C23),
Psilorhynchus pseudecheneis (C20), Pseudecheneis sulcata (C19), Garra gotyla (C11), and Opsarius shacra (C5) are positively related to conductivity, free carbondioxide and total hardness. One way analysis of variance on redundancy analysis (RDA) vindicated that among the selected parameters, $\mathrm{pH}$, air temperature and total hardness were the influencing factors $(P<0.05)$ to shape the fish community structure.

One-way permutational multivariate analysis of variance (perMANOVA) on the Non-metric Multidimensional Scaling (NMDS) showed no significant $(P>0.05)$ difference between winter, spring, and autumn season but summer season showed significant $(P<0.05)$ differences with winter, spring and autumn seasons. Furthermore, there was no substantial ( $P$ $>0.05$ ) difference in fish population structure of spatial variation between the various sampling stations. 

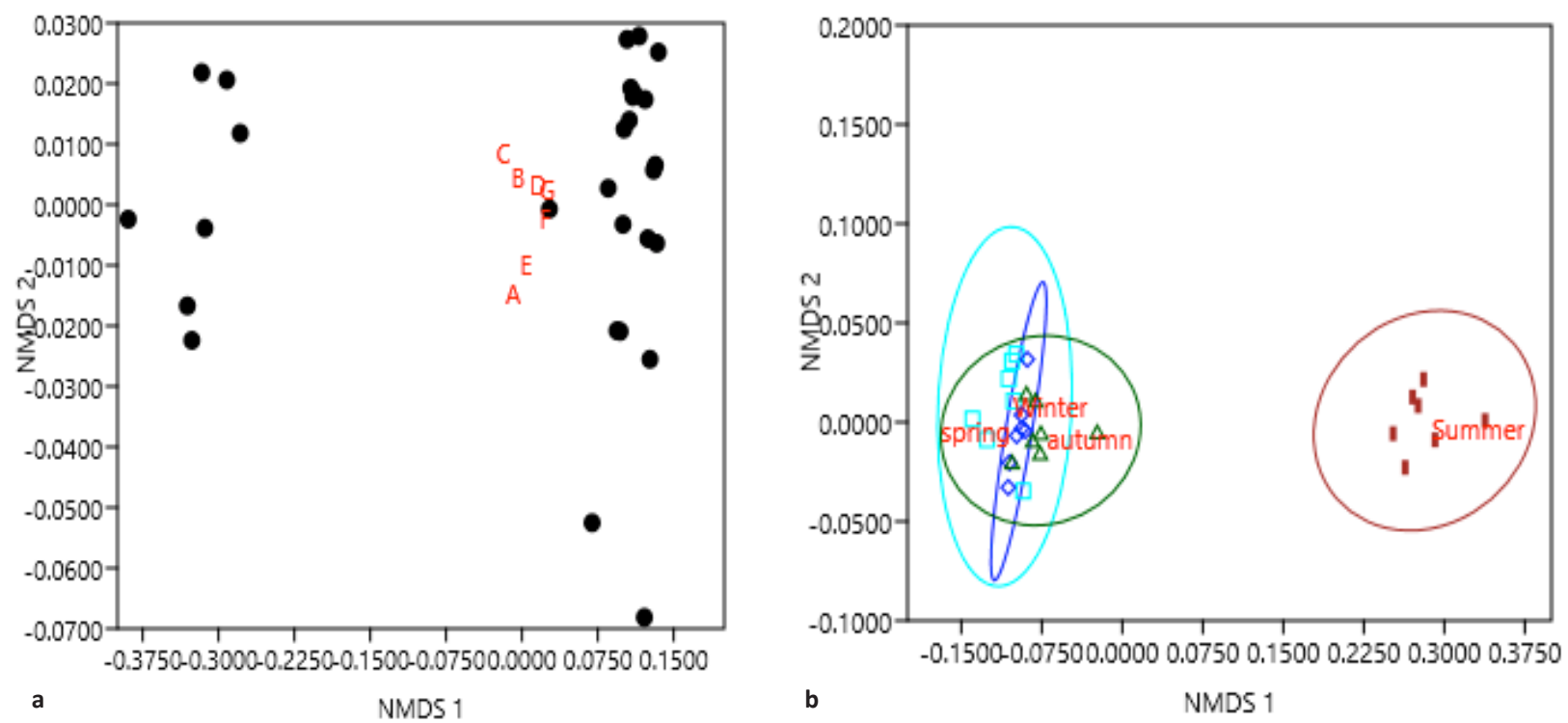

Figure 4. a-NMDS ordination of spatial variation of fish assemblage in the snow-fed Tamor River | b-NMDS ordination of temporal variation of fish assemblage in the snow-fed Tamor River.

Table 5. Season-wise fish faunal diversity indices in the snow-fed Tamor River, Nepal.

\begin{tabular}{|l|c|c|c|}
\hline Season & $\begin{array}{c}\text { Shannon Weiner } \\
\text { index }(H)\end{array}$ & $\begin{array}{c}\text { Simpson index } \\
\text { (D) }\end{array}$ & $\begin{array}{c}\text { Evenness index } \\
\text { (E) }\end{array}$ \\
\hline winter & $2.56 \pm 0.21$ & $0.90 \pm 0.02$ & $0.62 \pm 0.01$ \\
\hline spring & $2.703 \pm 0.12$ & $0.92 \pm 0.01$ & $0.63 \pm 0.01$ \\
\hline summer & $3.01 \pm 0.02$ & $0.94 \pm 0.003$ & $0.65 \pm 0.002$ \\
\hline autumn & $2.74 \pm 0.16$ & $0.92 \pm 0.01$ & $0.63 \pm 0.01$ \\
\hline
\end{tabular}

Edds (1993) and Dubey et al. (2012) observed that the environmental variables such as conductivity, DO, $\mathrm{pH}$, alkalinity, and salinity were most intensely correlated with the fish community composition of the Kali Gandaki River Basin, Nepal, and the Ganga River Basin, India. The most important environmental variables forming the fish assemblage in the Seti Gandaki River Basin were depth, width, conductivity, DO, F-CO2, SiO2 and chlorides. Some other variables such as, $\mathrm{pH}, \mathrm{PO} 43 \mathrm{i}$, chlorides and NO3-N were also important in structuring the fish communities (Pokhrel et al. 2018). The role of stream order in deciding the number and abundance of organisms has been clarified (Horwitz 1978; Payne 1986; Leveque 1997). Low temperature as well as other stressing physicochemical conditions are also usual in low order streams at high altitude (Bistoni \& Hued 2002).

\section{REFERENCES}

Ahikari, A., J.H. Limbu \& S. Pathak (2021). Fish Diversity and Water Quality Parameters of Mechi River, Jhapa, Province No. 1, Nepal. Borneo Journal of Resources Science and Technology 10(2): 24-34. https://doi.org/10.33736/bjrst.2954.2021

APHA (2012). Standard Methods for Examination of Water and Waste water. $22^{\text {nd }}$ Edn. American Public Health Association, Washington DC, USA, 1220

Bhatt, J.P. \& M.K. Pandit (2016). Endangered Golden mahseer Tor putitora Hamilton: a review of natural history. Review in Fish Biology and Fisheries 26: 25-38. https://doi.org/10.1007/s11160-015-9409-7

Biston, M.A. \& A.C. Hued (2002). Patterns of species richness in rivers of the central region of Argentina. Brazilian Journal of Biology 62: 753764. https://doi.org/10.1590/S1519-69842002000500004

Clarke, K.R. (1993). Non-parametric multivariate analyses of changes in community structure. Australian Journal of Ecology 18: 117-143. https://doi.org/10.1111/j.1442-9993.1993.tb00438.x

Conversi, A., V. Dakos, A. Gårdmark, S. Ling, C. Folke, J.P. Mumby, C. Greene, M. Edwards, T. Blenckner, M. Casini, A. Pershing, \& C. Möllmann (2015). A holistic view of marine regime shifts. Philosophical Transactions of the Royal Society B Biological Sciences 370: 1471-2970. https://doi.org/10.1098/rstb.2013.0279

Dudgeon, D, A. H. Arthington, M.O. Gessner, Z.I. Kawabata, D.J. Knowler et al. (2006). Freshwater biodiversity: Importance, threats, status and conservation challenges. Biological Reviews 81: 163-182. https://doi.org/10.1017/S1464793105006950

Edds, D.R. (1993). Fish assemblage structure and environmental correlates in Nepal's Gandaki River. Copeia 1993 (1): 48-60. https:// doi.org/10.2307/1446294

Gerhard, P, R. Maraes \& S. Molander (2004). Stream fish communities and their associations to habitat variables in a rain forest reserve in southeastern Brazil. Environmental Biology of Fishes 71: 321-330. https://doi.org/10.1007/s10641-004-1260-y

Gorman, O.T. (1988). The dynamics of habitat use in a guild of Ozark minnows. Ecological Monograph 58(1): 1-18. https://doi. org/10.2307/1942631

Grossmann, G.D, R.E. Ratajczak, J.M. Crawford \& M.C. Freemann (1998). Assemblages organization in stream fishes: effect of environmental variation and interspecific interactions Ecological Monograph 68: 
395-420. https://doi.org/10.2307/2657245

Harvey, B.C, \& A.J. Stewart (1991). Fish size and habitat depth relationship in headwater streams. Oecologia 87: 336-342. https:// doi.org/10.1007/BF00634588

Hill, M.O. \& H.G. Gauch (1980). Detrended correspondence analysis: an improved ordination technique. Vegetatio 42: 47-58. https://doi. org/10.1007/BF00048870

Horwitz, R. (1978). Temporal Variability Patterns and the Distributional Patterns of Stream Fishes. Ecological Monographs 48(3): 307-321. https://doi.org/10.2307/2937233

Hossain, M.S., N.G. Das, S. Sarker, \& M.Z. Rahaman (2012). Fish diversity and habitat relationship with Environmental vriables at Meghna river estuary, Bangladesh. Egyptian Journal of Aquatic Research 38: 213226. https://doi.org/10.1016/j.ejar.2012.12.006

Jayaram, K.C. (2010). The freshwater fishes of Indian region. Narendra Publishing House, Delhi, India, $614 \mathrm{pp}$.

Kadye, W.T., C.H.D. Magadza, N.A.G. Moyo \& S. Kativu (2008). Stream fish assemblages in relation to environmental factors on a montane plateau. Environmental Biology of Fishes 83: 417-428. https://doi. org/10.1007/s10641-008-9364-4

Legendre, P. \& L. Legendre (1998). Numerical Ecology. Second Edition. Elsevier, Amsterdam, Netherlands, 853 pp.

Leveque, C. (1997). Biodiversity dynamics and conservation: the freshwater fishes of tropical Africa. Cambridge University Press, UK

Limbu, J.H. \& A. Prasad (2020). Environmental variables and fisheries diversity of the Nuwa River, Panchthar, Nepal. Scientific World 13: 69-74. https://doi.org/10.3126/sw.v13i13.30542

Limbu, J.H., B. Bhurtel, A. Adhikari, G.C. Punam, M. Maharjan \& S. Sunuwar (2020). Fish community structure and environmental correlates in Nepal's Andhi Khola. Borneo Journal of Resources Science and Technology 10(2): 85-92. https://doi.org/10.33736/ bjrst. 2510.2020

Limbu, J.H., G.S. Acharya \& O.H. Shrestha (2018). A brief report on ichthyofaunal diversity of Dewmai Khola of Ilam district, Nepal. Journal of Natural History Museum 30: 312-317. https://doi. org/10.3126/jnhm.v30i0.27607

Limbu, J.H., J.K. Gurung, S. Subba, N. Khadka, A. Adhikari \& C.B. Baniya (2021b). An Impact Assessment of Betani Irrigation Dam on Fish Diversity of Damak Municipality, Jhapa, Nepal. Egyptian Journal of Aquatic Biology and Fisheries 25(2): 163-175. https://doi. org/10.21608/ejabf.2021.161363

Limbu, J.H., S, Subba, J.K. Gurung, J. Tumbahangfe \& B.R. Subba (2021a). Correlation of fish assemblages with habitat and environmental variables in the Phewa Khola Stream of Mangsebung Rural Municipality, Ilam, Nepal. Journal of Animal Diversity 3(1): $27-$ 36. http://doi.org/10.52547/JAD.2021.3.1.5

Magalhaes, M.F., D.C. Batalha \& M.J. CollaresPereora (2002). Gradient in stream fish assemblages across a Mediterranean landscape: contributions of environmental factors and spatial structure. Freshwater Biology 47: 1015-1031. https://doi.org/10.1046/j.13652427.2002.00830.x

Magurran, A.E. (1988). Ecological Diversity and its Measurement. Princeton University Press, Princeton.

McGill, B.J., B.J. Enquist, E. Weiher \& M. Westoby (2006). Rebuilding community ecology from functional traits. Trends in Ecology and Evolution 21: 178-185. https://doi.org/10.1016/j.tree.2006.02.002

Mishra, A.R. \& C.B. Baniya (2017). Ichthyofaunal diversity and physicochemical factors of Melamchi River, Sind-upalchok, Nepal. Journal of Institute of Science and Technology 21(1): 10-18. https://doi. org/10.3126/jist.v21i1.16031

Moyle, P.B. \& B. Vondracek (1985). Persistence and structure of the fish assemblage in a small California stream. Ecology 66: 1-13. https:// doi.org/10.2307/1941301

Ngor, P.B., P. Legendre, T. Oberdorff \& S. Lek (2018). Flow alterations by dams shaped fish assemblage dynamics in the complex Mekong3S river system. Ecological Indicators 88: 103-114. https://doi. org/10.1016/j.ecolind.2018.01.023

Payne, A.I. (1986). The ecology of tropical lakes and rivers. John Wiley $\&$ Sons, Britain
Perry, L.A., P.J. Low, J.R. Ellis \& J.D. Reynolds (2005). Climate change and distribution shifts in marine fishes. Science 308(5730): 1912-1915. https://doi.org/10.1126/science.1111322

Pielou, E.C. (1966). The measurement of diversity in different types of biological collections. Journal of Theoretical Biology 13: 131-144. https://doi.org/10.1016/0022-5193(66)90013-0

Pokharel, K.K., B.B. Khadga, C.M. Trilok \& C.B. Chitra (2018). Correlations between fish assemblage structure and environmental variables of the Seti Gandaki River Basin, Nepal. Journal of Freshwater Ecology 33(1): 31-43. https://doi.org/10.1080/02705060.2017.1399 170

Pinder, A.C., J.R. Britton, A.J. Harrison, P. Nautiyal, S.D. Bower, S.J. Cooke, S.L.M. Everard, UK.K. Ranjeet, S.W. Andy, N.D. Dahanukar \& R. Raghavan (2019). Mahseer (Tor spp.) fishes of the world: status, challenges and opportunities for conservation. Review of Fish Biology and Fisheries 29: 417-452. https://doi.org/10.1007/s11160-01909566-y(0123456789

Prasad, A., A. Shrestha, J.H. Limbu \& D. Swar (2020). Spatial and temporal variation of fish assemblage structure in Seti Gandaki River, Tanahu, Nepal. Borneo Journal of Resources Science and Technolog 10(2): 93-104. https://doi.org/10.33736/bjrst.2048.2020

Punam, G.C. \& J.H. Limbu (2019). Spatio-temporal variation of fish assemblages in Babai River of Danag district, Province No. 5, Nepal. Our Nature 17(1): 14-25. https://doi.org/10.3126/on.v17i1.33988

Rouyer, T., J.M. Fromentin, F. Me'nard, B. Cazelles, K. Briand, R. Pianet, B. Planque \& N.C. Stenseth (2008). Complex interplays among population dynamics, environmental forcing, and exploitation in fisheries. Proceedings of the National Academy of Sciences of the United States of America 105: 5420-5425.

Shah, R.B. (2016). Study of the freshwater fish diversity of Koshi River of Nepal. International Journals of Fauna and Biological Studies, 3(4): 78-81.

Shannon, C.E. \& W. Weave (1963). The Mathematical Theory of Communication. Urbana, IL: The University of Illinois Press, 117 pp.

Shrestha, J., D.M. Singh \& T.B. Saund (2009). Fish diversity of Tamor River and its major tributaries of eastern Himalayan region of Nepal. Nepal Journal of Science and Technology 10: 219-223. https://doi. org/10.3126/njst.v10i0.2964

Shrestha, J.N. (2016). Fish diversity of Triyuga River, Udayapur District. Our Nature 14(1): 124-134. https://doi.org/10.3126/on.v14i1.16452

Shrestha, T.K. (2019). Ichthyology of Nepal, a study of fishes of the Himalayan waters. Prism Color Scanning and Press Supportive Pvt. Ltd, Kathmandu, Nepal.

Spjøtvoll, E. \& M.R. Stoline (1973). An extension of the T-Method of multiple comparison to include the cases with unequal sample sizes. Journal of the American Statistical Association 68(344): 975-978. https://doi.org/10.1080/01621459.1973.10481458

Subba, B.R., N. Pokharel \& M.R. Pandey (2017). Ichthyofaunal diversity of Morang district, Nepal. Our Nature 15(12): 55-67. https://doi. org/10.3126/on.v15i1-2.18794

Swar, D.B. \& J. Shrestha (1998). Fishery baseline and impact assessment of Dudhkoshi-I hydropower project area. Mediun hydropower study project, NEA.

Swar, D.B. \& K.K. Upadhaya (1998). Fisheries baseline and impact assessment of Kabeli " $\mathrm{A}$ " hydropower project area. A report submitted to NEA

Talwar, P.K. \& A.G. Jhingram (1991). Inland Fisheries of India and Adjacent Countries. Volume I and II. Oxford and IBH Publishing Co. India, $1158 \mathrm{pp}$.

Wu, J., J. Wang, Y. He \& W. Cao (2011). Fish assemblage structure in the Chisui River, a protected tributary of the Yangtze River. Knowledge and Management of Aquatic Ecosystem 400(11): 1-14. https://doi. org $/ 10.1051 / \mathrm{kmae} / 2011023$

Yan, Y., H.E. Shan, C.H.U. Ling, X. Xiuying, J.I.A. Yanju, T.A.O. Juan \& C. Yifeng (2010). Spatial and temporal variation of fish assemblages in a subtropical small stream of the Huangshan Mountain. Current Zoology 56(6): 670-677. https://doi.org/10.1093/czoolo/56.6.670

Yu, S.L. \& T.W. Lee (2002). Habitat preference of the stream fish, Sinogastromyzon puliensis. Zoological Studies 41: 183-187. 
Appendix I. Determined values of environmental variables in different seasons and stations.

\begin{tabular}{|c|c|c|c|c|c|c|c|c|c|}
\hline Stations & Seasons & $\mathrm{pH}$ & WT & $\mathrm{FCO} 2$ & DO & ALK & $C D$ & wV & TH \\
\hline A & Winter & 7.1 & 17.6 & 7 & 8.6 & 17 & 55 & 1.9 & 34 \\
\hline B & Winter & 7 & 17.8 & 6.5 & 9 & 18 & 55 & 2 & 32 \\
\hline C & Winter & 6.5 & 17.5 & 7 & 8.7 & 18 & 56 & 1.8 & 31 \\
\hline D & Winter & 7 & 17 & 5 & 8 & 16.5 & 52 & 2 & 29 \\
\hline $\mathrm{E}$ & Winter & 7.4 & 17.5 & 6.5 & 7.9 & 16.6 & 53 & 2.2 & 23 \\
\hline $\mathrm{F}$ & Winter & 7.1 & 17.8 & 6 & 8.2 & 16.6 & 52 & 2.1 & 27 \\
\hline G & Winter & 6.5 & 17 & 7 & 8 & 15.5 & 51 & 1.9 & 28 \\
\hline A & spring & 6.5 & 17.1 & 5.9 & 8.6 & 15.4 & 52 & 1.9 & 30 \\
\hline B & spring & 7 & 17.6 & 6 & 9 & 15.4 & 51 & 2 & 36 \\
\hline C & spring & 7.2 & 18 & 6 & 8.9 & 17 & 51.5 & 1.5 & 34 \\
\hline D & spring & 6.5 & 19 & 6.4 & 8.4 & 17.5 & 54 & 1.8 & 35 \\
\hline $\mathrm{E}$ & spring & 7.2 & 18.6 & 7 & 8 & 17.5 & 52.4 & 2 & 34 \\
\hline $\mathrm{F}$ & spring & 7.4 & 18 & 6 & 8.4 & 16 & 50.1 & 1.9 & 36 \\
\hline G & spring & 7 & 18.5 & 7.5 & 8.6 & 17 & 52.3 & 2 & 37 \\
\hline A & Summer & 6.5 & 18.9 & 7 & 8.9 & 17.5 & 52 & 1.8 & 40 \\
\hline B & Summer & 7.8 & 18.4 & 6 & 7.9 & 17.5 & 53.1 & 1.7 & 39 \\
\hline C & Summer & 7.7 & 15.9 & 6.8 & 8 & 16.5 & 53 & 1.9 & 38 \\
\hline D & Summer & 7.9 & 17 & 6.9 & 8.3 & 16.5 & 52 & 1.7 & 39 \\
\hline $\mathrm{E}$ & Summer & 7.5 & 19 & 7 & 8.6 & 17 & 54 & 1.7 & 40 \\
\hline $\mathrm{F}$ & Summer & 7.8 & 18.9 & 6.8 & 8.8 & 18 & 52 & 1.6 & 41 \\
\hline G & Summer & 7.6 & 19 & 7 & 9 & 18 & 53 & 1.9 & 39 \\
\hline A & autumn & 7.5 & 15 & 5 & 8 & 16 & 55 & 2 & 40 \\
\hline B & autumn & 7 & 17 & 6 & 9 & 19 & 45 & 2.3 & 24 \\
\hline C & autumn & 8 & 17.5 & 8 & 7 & 18 & 56 & 2.5 & 28 \\
\hline D & autumn & 6 & 18 & 6 & 8 & 17 & 49 & 2.9 & 37 \\
\hline $\mathrm{E}$ & autumn & 7 & 18.3 & 9 & 8 & 16 & 53 & 3 & 35 \\
\hline $\mathrm{F}$ & autumn & 7.3 & 18 & 6 & 9 & 17 & 60 & 2.7 & 39 \\
\hline G & autumn & 8 & 18.5 & 7 & 8 & 15 & 77 & 1.6 & 40 \\
\hline
\end{tabular}




\begin{tabular}{|c|c|c|c|c|c|c|c|c|c|c|c|c|c|c|c|c|c|c|c|c|c|c|c|c|c|c|c|c|}
\hline & 0 & $\circ$ & 0 & 0 & 10 & 0 & -7 & $\infty$ & $m$ & $\approx$ & I & 9 & 6 & $\exists$ & $\widetilde{m}$ & $\approx$ & 오 & $\stackrel{\infty}{\sim}$ & a & 省 & $n$ & 0 & 0 & $\sigma$ & $\infty$ & 0 & & -1 \\
\hline & & - & $\sigma$ & ר & 0 & $c$ & & $\circ$ & & & & & 0 & & & 0 & & 0 & 0 & $\circ$ & 0 & 0 & $r$ & $\sigma$ & o & ○ & 0 & 0 \\
\hline & $\stackrel{9}{9}$ & $\sigma$ & $\infty$ & $=$ & 0 & & & & & & & & $\stackrel{m}{\mu}$ & & $\vec{m}$ & $\vec{m}$ & & $\stackrel{2}{2}$ & $\stackrel{\sim}{\sim}$ & $\stackrel{\sim}{ \pm}$ & $\overbrace{\sim}^{\infty}$ & $\approx$ & $\vec{\exists}$ & $\sigma$ & $m$ & $\sim$ & $\stackrel{1}{0}$ & $\approx$ \\
\hline & $\approx$ & $\approx$ & 7 & $\sigma$ & $c$ & & & & & $\approx$ & & & -1 & & $\exists$ & $a$ & & $\vec{N}$ & i & d & 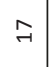 & $\vec{F}$ & $a$ & $m$ & $\rightarrow$ & r & $\sigma$ & . \\
\hline & & $\sim$ & $r$ & n & c & 0 & 0 & 7 & & $m$ & 0 & & 0 & & b & 0 & 0 & 0 & 0 & 0 & 0 & 0 & $\rightarrow$ & 0 & 0 & ○ & 0 & o \\
\hline & -7 & 0 & 0 & in & 0 & $\exists$ & $\sim$ & o & 0 & 0 & -1 & 0 & $\sim$ & & ભ & r & $\Leftrightarrow$ & 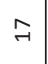 & $\stackrel{\sim}{\sim}$ & $\stackrel{\circ}{\sim}$ & $\stackrel{\sim}{0}$ & 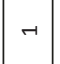 & $\sim$ & 0 & ○ & $m$ & H & $\sim$ \\
\hline & 0 & in & $\sigma$ & -7 & 7 & 0 & 0 & $r$ & $\sim$ & 0 & | & -1 & 0 & $N$ & $\infty$ & $\wedge$ & $\sigma$ & $\approx$ & $\approx$ & $F$ & $\sigma$ & 0 & $\rightarrow$ & 0 & 0 & ○ & 0 & 0 \\
\hline & $\circ$ & 0 & 0 & 0 & 0 & in & $\sigma$ & 0 & 0 & 0 & $\circ$ & 0 & - & 0 & ○ & 0 & $\circ$ & 0 & 0 & 0 & $\circ$ & 0 & 0 & 0 & 0 & ○ & $\rightarrow$ & 0 \\
\hline & $\Xi$ & $\exists$ & $\stackrel{\infty}{\sim}$ & o & 峞 & $a$ & $\sigma$ & 9 & $\approx$ & $\sigma$ & $\underset{\sim}{\mathbf{2}}$ & n & $\stackrel{\sim}{\sim}$ & o & $\underset{\sim}{\infty}$ & $\stackrel{m}{q}$ & 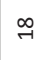 & $\stackrel{\mathscr{N}}{ }$ & $\stackrel{m}{m}$ & $\tilde{m}$ & $\stackrel{\infty}{\sim}$ & $\approx$ & $a$ & 0 & 익 & $\infty$ & $\nabla$ & $a$ \\
\hline U & $\sim$ & 0 & $\infty$ & $a$ & r & $m$ & $\rightarrow$ & 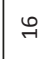 & $\sigma$ & $m$ & 6 & $\approx$ & $a$ & N & $\lesssim$ & $\stackrel{\sim}{\circ}$ & $\stackrel{\overbrace{}}{\longrightarrow}$ & $\approx$ & 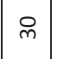 & i & $\stackrel{m}{~}$ & $\stackrel{m}{m}$ & $\approx$ & a & + & -1 & 0 & 0 \\
\hline & i & $\infty$ & $m$ & $\stackrel{\sim}{\sim}$ & 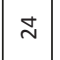 & 6 & $\infty$ & $\approx$ & $\stackrel{m}{q}$ & $\wedge$ & 。 & $\approx$ & $\stackrel{\bullet}{\longrightarrow}$ & $F$ & $\stackrel{m}{q}$ & $\approx$ & ㅇ & $\stackrel{\sim}{2}$ & $a$ & I & 9 & $\vec{F}$ & $\stackrel{\infty}{\sim}$ & 0 & $\rightarrow$ & $\sigma$ & $\sigma$ & $\approx$ \\
\hline & $\sigma$ & 0 & 0 & 0 & 0 & $-r$ & 6 & 0 & 0 & 0 & $\circ$ & 0 & $m$ & - & i & 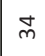 & $\hat{n}$ & gi & 8 & $m$ & ஜ & $\stackrel{m}{\sim}$ & 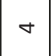 & $r$ & $\approx$ & $\sim$ & $\infty$ & $\Rightarrow$ \\
\hline & 0 & $-r$ & m & $\infty$ & 10 & 0 & in & & -1 & 0 & m & 0 & 0 & ○ & ๙ & $\approx$ & $\stackrel{\infty}{\sim}$ & $\approx$ & $\stackrel{\sim}{\sim}$ & $\stackrel{\infty}{\sim}$ & $\exists$ & $\approx$ & $\infty$ & $m$ & $\sim$ & n & 0 & o \\
\hline & $m$ & - & 0 & 0 & $m$ & + & $\sim$ & 0 & - & $\sim$ & 0 & 。 & $\rightarrow$ & ॰ & \% & $\stackrel{\sim}{\sim}$ & g & $\stackrel{\sim}{N}$ & 望 & ন & I & $\vec{A}$ & in & $\sim$ & ○ & ○ & $\neg$ & $\infty$ \\
\hline & 이 & $a$ & m & -7 & $\vec{\nabla}$ & 0 & 0 & $\overrightarrow{7}$ & $\approx$ & $\sigma$ & in & $\approx$ & $\infty$ & a & 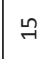 & $\underset{\sim}{-\infty}$ & $\stackrel{\sim}{\sim}$ & $\stackrel{m}{m}$ & $\nexists$ & $\approx$ & $\stackrel{m}{m}$ & $\vec{A}$ & $\approx$ & a & 9 & $\approx$ & $\sigma$ & I \\
\hline & in & H & ○ & $\rightarrow$ & 0 & $m$ & $\infty$ & & $\infty$ & 0 & $\sigma$ & $m$ & $\rightarrow$ & 0 & i & $\stackrel{n}{\sim}$ & $\approx$ & i & $\vec{\sim}$ & $\stackrel{\sim}{\sim}$ & $\approx$ & $\wedge$ & $\approx$ & a & $\nabla$ & - & $\sigma$ & ब \\
\hline & 9 & $\stackrel{n}{\rightarrow}$ & $\approx$ & 0 & 0 & $a$ & $\approx$ & - & $\stackrel{\sim}{\circ}$ & $\infty$ & ナ & $\infty$ & 0 & - & $\infty$ & $\approx$ & $\approx$ & I & $\infty$ & $f$ & 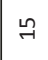 & $\stackrel{\sim}{\sim}$ & $m$ & a & $\stackrel{\infty}{\rightarrow}$ & $\sim$ & $\approx$ & $\sigma$ \\
\hline & A & 0 & $\sigma$ & $\rightarrow$ & 0 & 잉 & 0 & & in & 0 & 0 & $m$ & $\sigma$ & N & $\bar{\pi}$ & $\vec{\lambda}$ & $\tilde{N}$ & I & $\mathscr{m}$ & i & $\stackrel{\infty}{\sim}$ & $\approx$ & $\sigma$ & in & $\rightarrow$ & ○ & 0 & $\vec{\top}$ \\
\hline & n & $F$ & $\stackrel{\infty}{\infty}$ & in & $\stackrel{\sim}{\sim}$ & $\sim$ & $\stackrel{\sim}{\sim}$ & & $\approx$ & $\sigma$ & 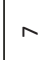 & $\simeq$ & - & a & I & $\stackrel{\sim}{~}$ & $\tilde{m}$ & I & $\underset{\sim}{\stackrel{\infty}{\sim}}$ & i & d & $\approx$ & $m$ & $\infty$ & $\approx$ & N & $m$ & ب \\
\hline & 0 & 0 & $\rightarrow$ & o & $N$ & - & $c$ & & 0 & $N$ & -1 & $\circ$ & 0 & 0 & & 0 & & 0 & 0 & 0 & 0 & 0 & 0 & o & 0 & ○ & 0 & 0 \\
\hline & 6 & n & -1 & $\neg$ & - & $m$ & 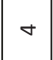 & & -1 & 0 & $m$ & $\infty$ & $\sim$ & $m$ & & $\vec{\lambda}$ & ㅇ & $\infty$ & 9 & $\stackrel{\sim}{\sim}$ & i & $F$ & $a$ & in & $\approx$ & 9 & $m$ & 。 \\
\hline & 0 & 0 & $\bullet$ & ナ & -7 & $\sigma$ & $c$ & & $\sim$ & $\nexists$ & $\stackrel{\sim}{\sim}$ & $\approx$ & $a$ & o & $\stackrel{\sim}{\sim}$ & $\approx$ & $\circ$ & $\stackrel{\text { D }}{ }$ & ন & $\stackrel{\sim}{\sim}$ & I & $\sigma$ & $\stackrel{0}{7}$ & 0 & $m$ & $a$ & $\exists$ & I \\
\hline & $\infty$ & 0 & $\sigma$ & ナ & $\approx$ & $\vec{N}$ & 0 & & $\approx$ & $\sigma$ & $\infty$ & -1 & $r$ & $F$ & & $\approx$ & 0 & 9 & 국 & i & $\approx$ & $\approx$ & $a$ & $\stackrel{\sim}{\sim}$ & $\stackrel{\eta}{\sim}$ & $\sigma$ & -1 & N \\
\hline & $\sim$ & in & $\sigma$ & -1 & 0 & o & $c$ & 0 & $\rightarrow$ & $\sigma$ & - & $m$ & 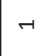 & - & 9 & i & 8 & $\stackrel{\infty}{\sim}$ & $\vec{m}$ & $\stackrel{m}{m}$ & 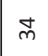 & $\stackrel{m}{\sim}$ & in & $\sigma$ & -1 & -1 & 0 & $m$ \\
\hline & $F$ & in & 욤 & $\vec{F}$ & 9 & $m$ & 10 & & $m$ & $\wedge$ & -1 & 0 & 욱 & - & $\stackrel{m}{q}$ & g & 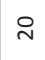 & $g$ & $\stackrel{\sim}{\sim}$ & I & $\infty$ & $\approx$ & $a$ & $\nabla$ & $\exists$ & $\infty$ & 0 & - \\
\hline & in & $\sigma$ & 0 & $m$ & in & $\infty$ & $\rightarrow$ & & $m$ & -7 & 0 & $m$ & स & $\sigma$ & 9 & $\stackrel{\sim}{\sim}$ & 0 & $\stackrel{\infty}{\infty}$ & $\stackrel{\sim}{\circ}$ & $\underset{\sim}{\infty}$ & $\stackrel{\infty}{\sim}$ & $\sigma$ & 0 & - & $\sim$ & $a$ & o & N \\
\hline & o & 0 & 0 & $\circ$ & | & $\circ$ & $r$ & 0 & $\circ$ & $\circ$ & 10 & $\circ$ & 0 & o & $\circ$ & 0 & $\circ$ & 0 & 0 & 0 & 0 & 0 & 0 & 。 & 0 & o & $\rightarrow$ & ナ \\
\hline & $\circ$ & 4 & 0 & 0 & 0 & $\circ$ & 0 & 0 & $\circ$ & 0 & 0 & 0 & 0 & ○ & 0 & 0 & $\circ$ & 0 & 0 & 0 & 0 & $\rightarrow$ & $\sim$ & 0 & 0 & o & 0 & 0 \\
\hline$\stackrel{\circ}{\circ}$ & 离 & 离 & $\mid \begin{array}{l}\text { 离 } \\
\text { 竎 }\end{array}$ & $\mid \begin{array}{l}\bar{y} \\
\bar{y} \\
\bar{z}\end{array}$ & $\mid \begin{array}{l}\bar{y} \\
\bar{y} \\
\bar{y}\end{array}$ & 离 & 离 & 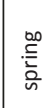 & 䇏 & 變 & 童 & 을 & 窝 & 童 & 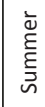 & 点 & 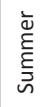 & 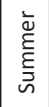 & 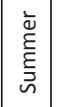 & 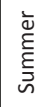 & 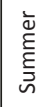 & 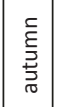 & 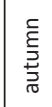 & 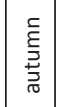 & & 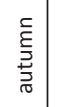 & & ह్ \\
\hline & & $\infty$ & u & 0 & س & « & 0 & $\varangle$ & $\infty$ & $u$ & $\circ$ & ш & 4 & 0 & $\varangle$ & $\infty$ & u & 0 & ш & ч & 0 & $\varangle$ & $\infty$ & 0 & & & & | \\
\hline
\end{tabular}



Dr. John Noyes, Natural History Museum, London, UK

Dr. Albert G. Orr, Griffith University, Nathan, Australia

Dr. Sameer Padhye, Katholieke Universiteit Leuven, Belgium

Dr. Nancy van der Poorten, Toronto, Canada

Dr. Kareen Schnabel, NIWA, Wellington, New Zealand

Dr. R.M. Sharma, (Retd.) Scientist, Zoological Survey of India, Pune, India

Dr. Manju Siliwal, WILD, Coimbatore, Tamil Nadu, India

Dr. G.P. Sinha, Botanical Survey of India, Allahabad, India

Dr. K.A. Subramanian, Zoological Survey of India, New Alipore, Kolkata, India

Dr. P.M. Sureshan, Zoological Survey of India, Kozhikode, Kerala, India

Dr. R. Varatharajan, Manipur University, Imphal, Manipur, India

Dr. Eduard Vives, Museu de Ciències Naturals de Barcelona, Terrassa, Spain

Dr. James Young, Hong Kong Lepidopterists' Society, Hong Kong

Dr. R. Sundararaj, Institute of Wood Science \& Technology, Bengaluru, India

Dr. M. Nithyanandan, Environmental Department, La Ala Al Kuwait Real Estate. Co. K.S.C.,

Kuwait

Dr. Himender Bharti, Punjabi University, Punjab, India

Mr. Purnendu Roy, London, UK

Dr. Saito Motoki, The Butterfly Society of Japan, Tokyo, Japan

Dr. Sanjay Sondhi, TITLI TRUST, Kalpavriksh, Dehradun, India

Dr. Nguyen Thi Phuong Lien, Vietnam Academy of Science and Technology, Hanoi, Vietnam

Dr. Nitin Kulkarni, Tropical Research Institute, Jabalpur, India

Dr. Robin Wen Jiang Ngiam, National Parks Board, Singapore

Dr. Lional Monod, Natural History Museum of Geneva, Genève, Switzerland.

Dr. Asheesh Shivam, Nehru Gram Bharti University, Allahabad, India

Dr. Rosana Moreira da Rocha, Universidade Federal do Paraná, Curitiba, Brasi

Dr. Kurt R. Arnold, North Dakota State University, Saxony, Germany

Dr. James M. Carpenter, American Museum of Natural History, New York, USA

Dr. David M. Claborn, Missouri State University, Springfield, USA

Dr. Kareen Schnabel, Marine Biologist, Wellington, New Zealand

Dr. Amazonas Chagas Júnior, Universidade Federal de Mato Grosso, Cuiabá, Brasil

Mr. Monsoon Jyoti Gogoi, Assam University, Silchar, Assam, India

Dr. Heo Chong Chin, Universiti Teknologi MARA (UiTM), Selangor, Malaysia

Dr. R.J. Shiel, University of Adelaide, SA 5005, Australia

Dr. Siddharth Kulkarni, The George Washington University, Washington, USA

Dr. Priyadarsanan Dharma Rajan, ATREE, Bengaluru, India

Dr. Phil Alderslade, CSIRO Marine And Atmospheric Research, Hobart, Australia

Dr. John E.N. Veron, Coral Reef Research, Townsville, Australia

Dr. Daniel Whitmore, State Museum of Natural History Stuttgart, Rosenstein, Germany.

Dr. Yu-Feng Hsu, National Taiwan Normal University, Taipei City, Taiwan

Dr. Keith V. Wolfe, Antioch, California, USA

Dr. Siddharth Kulkarni, The Hormiga Lab, The George Washington University, Washington,

D.C., USA

Dr. Tomas Ditrich, Faculty of Education, University of South Bohemia in Ceske

Budejovice, Czech Republic

Dr. Mihaly Foldvari, Natural History Museum, University of Oslo, Norway

Dr. V.P. Uniyal, Wildlife Institute of India, Dehradun, Uttarakhand 248001, India

Dr. John T.D. Caleb, Zoological Survey of India, Kolkata, West Bengal, India

Dr. Priyadarsanan Dharma Rajan, Ashoka Trust for Research in Ecology and the Environment

(ATREE), Royal Enclave, Bangalore, Karnataka, India

\section{Fishes}

Dr. Neelesh Dahanukar, IISER, Pune, Maharashtra, India

Dr. Topiltzin Contreras MacBeath, Universidad Autónoma del estado de Morelos, México

Dr. Heok Hee Ng, National University of Singapore, Science Drive, Singapore

Dr. Rajeev Raghavan, St. Albert's College, Kochi, Kerala, India

Dr. Robert D. Sluka, Chiltern Gateway Project, A Rocha UK, Southall, Middlesex, UK

Dr. E. Vivekanandan, Central Marine Fisheries Research Institute, Chennai, India

Dr. Davor Zanella, University of Zagreb, Zagreb, Croatia

Dr. A. Biju Kumar, University of Kerala, Thiruvananthapuram, Kerala, India

Dr. Akhilesh K.V., ICAR-Central Marine Fisheries Research Institute, Mumbai Research

Centre, Mumbai, Maharashtra, India

Dr. J.A. Johnson, Wildlife Institute of India, Dehradun, Uttarakhand, India

Amphibians

Dr. Sushil K. Dutta, Indian Institute of Science, Bengaluru, Karnataka, India

Dr. Annemarie Ohler, Muséum national d'Histoire naturelle, Paris, France

\section{Reptiles}

Dr. Gernot Vogel, Heidelberg, Germany

Dr. Raju Vyas, Vadodara, Gujarat, India

Dr. Pritpal S. Soorae, Environment Agency, Abu Dubai, UAE.

Prof. Dr. Wayne J. Fuller, Near East University, Mersin, Turkey

Prof. Chandrashekher U. Rivonker, Goa University, Taleigao Plateau, Goa. India

Dr. S.R. Ganesh, Chennai Snake Park, Chennai, Tamil Nadu, India

Dr. Himansu Sekhar Das, Terrestrial \& Marine Biodiversity, Abu Dhabi, UAE
Birds

Dr. Hem Sagar Baral, Charles Sturt University, NSW Australia

Dr. Chris Bowden, Royal Society for the Protection of Birds, Sandy, UK

Dr. Priya Davidar, Pondicherry University, Kalapet, Puducherry, India

Dr. J.W. Duckworth, IUCN SSC, Bath, UK

Dr. Rajah Jayapal, SACON, Coimbatore, Tamil Nadu, India

Dr. Rajiv S. Kalsi, M.L.N. College, Yamuna Nagar, Haryana, India

Dr. V. Santharam, Rishi Valley Education Centre, Chittoor Dt., Andhra Pradesh, India

Dr. S. Balachandran, Bombay Natural History Society, Mumbai, India

Mr. J. Praveen, Bengaluru, India

Dr. C. Srinivasulu, Osmania University, Hyderabad, India

Dr. K.S. Gopi Sundar, International Crane Foundation, Baraboo, USA

Dr. Gombobaatar Sundev, Professor of Ornithology, Ulaanbaatar, Mongolia

Prof. Reuven Yosef, International Birding \& Research Centre, Eilat, Israel

Dr. Taej Mundkur, Wetlands International, Wageningen, The Netherlands

Dr. Carol Inskipp, Bishop Auckland Co., Durham, UK

Dr. Tim Inskipp, Bishop Auckland Co, Durham, UK

Dr. V. Gokula, National College, Tiruchirappalli, Tamil Nadu, India

Dr. Arkady Lelej, Russian Academy of Sciences, Vladivostok, Russia

Dr. Simon Dowell, Science Director, Chester Zoo, UK

Dr. Mário Gabriel Santiago dos Santos, Universidade de Trás-os-Montes e Alto Douro,

Quinta de Prados, Vila Real, Portugal

Dr. Grant Connette, Smithsonian Institution, Royal, VA, USA

Dr. M. Zafar-ul Islam, Prince Saud Al Faisal Wildlife Research Center, Taif, Saudi Arabia

Mammals

Dr. Giovanni Amori, CNR - Institute of Ecosystem Studies, Rome, Italy

Dr. Anwaruddin Chowdhury, Guwahati, India

Dr. David Mallon, Zoological Society of London, UK

Dr. Shomita Mukherjee, SACON, Coimbatore, Tamil Nadu, India

Dr. Angie Appel, Wild Cat Network, Germany

Dr. P.O. Nameer, Kerala Agricultural University, Thrissur, Kerala, India

Dr. Ian Redmond, UNEP Convention on Migratory Species, Lansdown, UK

Dr. Heidi S. Riddle, Riddle's Elephant and Wildlife Sanctuary, Arkansas, USA

Dr. Karin Schwartz, George Mason University, Fairfax, Virginia.

Dr. Lala A.K. Singh, Bhubaneswar, Orissa, India

Dr. Mewa Singh, Mysore University, Mysore, India

Dr. Paul Racey, University of Exeter, Devon, UK

Dr. Honnavalli N. Kumara, SACON, Anaikatty P.O., Coimbatore, Tamil Nadu, India

Dr. Nishith Dharaiya, HNG University, Patan, Gujarat, India

Dr. Spartaco Gippoliti, Socio Onorario Società Italiana per la Storia della Fauna "Giuseppe

Altobello", Rome, Italy

Dr. Justus Joshua, Green Future Foundation, Tiruchirapalli, Tamil Nadu, India

Dr. H. Raghuram, The American College, Madurai, Tamil Nadu, India

Dr. Paul Bates, Harison Institute, Kent, UK

Dr. Jim Sanderson, Small Wild Cat Conservation Foundation, Hartford, USA

Dr. Dan Challender, University of Kent, Canterbury, UK

Dr. David Mallon, Manchester Metropolitan University, Derbyshire, UK

Dr. Brian L. Cypher, California State University-Stanislaus, Bakersfield, CA

Dr. S.S. Talmale, Zoological Survey of India, Pune, Maharashtra, India

Prof. Karan Bahadur Shah, Budhanilakantha Municipality, Kathmandu, Nepal

Dr. Susan Cheyne, Borneo Nature Foundation International, Palangkaraja, Indonesia

Dr. Hemanta Kafley, Wildlife Sciences, Tarleton State University, Texas, USA

\section{Other Disciplines}

Dr. Aniruddha Belsare, Columbia MO 65203, USA (Veterinary)

Dr. Mandar S. Paingankar, University of Pune, Pune, Maharashtra, India (Molecular)

Dr. Jack Tordoff, Critical Ecosystem Partnership Fund, Arlington, USA (Communities)

Dr. Ulrike Streicher, University of Oregon, Eugene, USA (Veterinary)

Dr. Hari Balasubramanian, EcoAdvisors, Nova Scotia, Canada (Communities)

Dr. Rayanna Hellem Santos Bezerra, Universidade Federal de Sergipe, São Cristóvão, Brazil

Dr. Jamie R. Wood, Landcare Research, Canterbury, New Zealand

Dr. Wendy Collinson-Jonker, Endangered Wildlife Trust, Gauteng, South Africa

Dr. Rajeshkumar G. Jani, Anand Agricultural University, Anand, Gujarat, India

Dr. O.N. Tiwari, Senior Scientist, ICAR-Indian Agricultural Research Institute (IARI), New

Delhi, India

Dr. L.D. Singla, Guru Angad Dev Veterinary and Animal Sciences University, Ludhiana, India

Dr. Rupika S. Rajakaruna, University of Peradeniya, Peradeniya, Sri Lanka

Dr. Bahar Baviskar, Wild-CER, Nagpur, Maharashtra 440013, India

Reviewers 2018-2020

Due to pausity of space, the list of reviewers for $2018-2020$ is available online.

The opinions expressed by the authors do not reflect the views of the Journal of Threatened Taxa, Wildlife Information Liaison Development Society, Zoo Outreach Organization, or any of the partners. The journal, the publisher, the host, and the partners are not responsible for the accuracy of the political boundaries shown in the maps by the authors.

Journal of Threatened Taxa is indexed/abstracted in Bibliography of Systematic Mycology, Biological Abstracts, BIOSIS Previews, CAB Abstracts, EBSCO, Google Scholar, Index Copernicus, Index Fungorum, JournalSeek, National Academy of Agricultural Sciences, NewJour, OCLC WorldCat, SCOPUS, Stanford University Libraries, Virtual Library of Biology, Zoological Records.

NAAS rating (India) 5.64
Print copies of the Journal are available at cost. Write to:

The Managing Editor, JoTT,

c/o Wildlife Information Liaison Development Society,

No. 12, Thiruvannamalai Nagar, Saravanampatti - Kalapatti Road,

Saravanampatti, Coimbatore, Tamil Nadu 641035, India

ravi@threatenedtaxa.org 


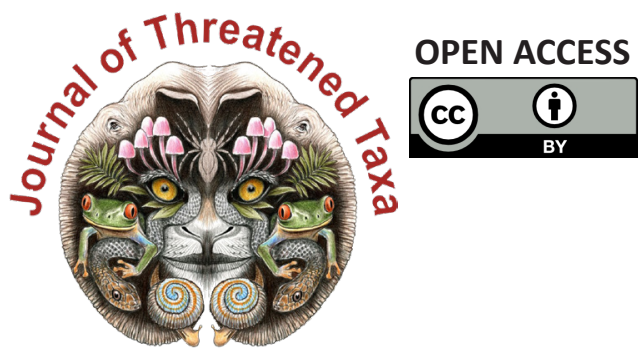

www.threatenedtaxa.org

The Journal of Threatened Taxa (JoTT) is dedicated to building evidence for conservation globally by publishing peer-reviewed articles online every month at a reasonably rapid rate at www.threatenedtaxa.org. All articles published in JoTT are registered under Creative Commons Attribution 4.0 International License unless otherwise mentioned. JoTT allows allows unrestricted use, reproduction, and distribution of articles in any medium by providing adequate credit to the author(s) and the source of publication.

\section{ISSN $0974-7907$ (Online) | ISSN $0974-7893$ (Print)}

\section{December 2021 | Vol. 13 | No. 14 | Pages: 20143-20310 \\ Date of Publication: 26 December 2021 (Online \& Print) DOI: 10.11609/jott.2021.13.14.20143-20310}

\section{Communications}

Updated distribution of seven Trichosanthes L. (Cucurbitales: Cucurbitaceae) taxa in India, along with taxonomic notes

Kanakasabapathi Pradheep, Soyimchiten, Ganjalagatta Dasaiah Harish, Muhammed Abdul Nizar, Kailash Chandra Bhatt, Anjula Pandey \& Sudhir Pal Ahlawat, Pp. 20143-20152

Dragonflies and Damselflies (Insecta: Odonata) of Aryanad Grama Panchayat, Kerala, India

- Reji Chandran \& A. Vivek Chandran, Pp. 20153-20166

Checklist of Odonata (Insecta) of Doon Valley, Uttarakhand, India

- Kritish De, Sarika Bhatt, Amar Paul Singh, Manisha Uniyal \& Virendra Prasad Uniyal, Pp. 20167-20173

Diversity of moths from the urban set-up of Valmiki Nagar, Chennai, India - Vikas Madhav Nagarajan, Rohith Srinivasan \& Mahathi Narayanaswamy, Pp. 20174-20189

Ichthyofaunal diversity with relation to environmental variables in the snowfed Tamor River of eastern Nepal

- Jawan Tumbahangfe, Jash Hang Limbu, Archana Prasad, Bhrarat Raj Subba \& Dil Kumar Limbu, Pp. 20190-20200

Observations on the foraging behavior of Tricoloured Munia Lonchura malacca (Linnaeus, 1766) and its interaction with pearl millet fields in Villupuram District, Tamil Nadu, India

- M. Pandian, Pp. 20201-20208

Roosting patterns of House Sparrow Passer domesticus Linn., 1758 (Aves: Passeridae) in Bhavnagar, Gujarat, India

- Foram P. Patel \& Pravinsang P. Dodia, Pp. 20209-20217

Review

Comprehensive checklist of algal class Chlorophyceae (sensu Fritsch, 1935) for Uttar Pradesh, India, with updated taxonomic status

- Sushma Verma, Kiran Toppo \& Sanjeeva Nayaka, Pp. 20218-20248

\section{View Point}

Wildlife managers ignore previous knowledge at great risk: the case of Rivaldo, the iconic wild Asian Elephant Elephas maximus L. of the Sigur Region, Nilgiri Biosphere Reserve, India

- Jean-Philippe Puyravaud \& Priya Davidar, Pp. 20249-20252

\section{Short Communications}

Diversity and distribution of macro lichens from Kalpetta Municipality of Wayanad District, Kerala, India

- Greeshma Balu, A.R. Rasmi, Stephen Sequeira \& Biju Haridas, Pp. 20253-20257

Extended distribution of two endemic epiphytes from the Western Ghats to the Deccan Plateau

- Sonali Vishnu Deore, Mangala Dala Sonawane \& Sharad Suresh Kambale, Pp. 20258-20260

Nomenclatural notes and report of Boehmeria penduliflora Wedd. ex D.G. Long from the Terai region of Uttar Pradesh, India

- Amit Gupta, Imtiyaz Ahmad Hurrah, Aparna Shukla \& Vijay V. Wagh, Pp. 2026120265
New distribution record of a true coral species, Psammocora contigua (Esper, 1794) from Gulf of Kachchh Marine National Park \& Sanctuary, India - R. Chandran, R. Senthil Kumaran, D.T. Vasavada, N.N. Joshi \& Osman G. Husen, Pp. 20266-20271

A new species of flat-headed mayfly Afronurus meenmutti (Ephemeroptera: Heptageniidae: Ecdyonurinae) from Kerala, India

- Marimuthu Muthukatturaja \& Chellaiah Balasubramanian, Pp. 20272-20277

Photographic record of Dholes predating on a young Banteng in southwestern Java, Indonesia

- Dede Aulia Rahman, Mochamad Syamsudin, Asep Yayus Firdaus, Herry Trisna Afriandi \& Anggodo, Pp. 20278-20283

Latrine site and its use pattern by Large Indian Civet Viverra zibetha Linnaeus, 1758: record from camera trap

- Bhuwan Singh Bist, Prashant Ghimire, Basant Sharma, Chiranjeevi Khanal \& Anoj Subedi, Pp. 20284-20287

Notes

Two additions to the flora of Kerala, India

- P. Murugan, Basil Paul \& M. Sulaiman, Pp. 20288-20291

Pentatropis R.Br. ex Wight \& Arn. (Apocynaceae), a new generic record for Kerala, India

- V. Ambika, Jose Sojan \& V. Suresh, Pp. 20292-20294

New record of Kashmir Birch Mouse Sicista concolor leathemi (Thomas, 1893) (Rodentia: Sminthidae) in the Indian Himalaya

- S.S. Talmale, Avtar Kaur Sidhu \& Uttam Saikia, Pp. 20295-20298

Breeding record of Black-headed Ibis Threskiornis melanocephalus (Aves: Threskiornithidae) at Mavoor wetland, Kozhikode District, Kerala, India - C.T. Shifa, Pp. 20299-20301

\section{Response}

Crop and property damage caused by Purple-faced Langurs Trachypithecus vetulus (Mammalia: Primates: Cercopithecidae) - Vincent Nijman, Pp. 20302-20306

Reply

If habitat heterogeneity is effective for conservation of butterflies in urban landscapes of Delhi, India? Unethical publication based on data manipulation: Response of original authors

- Monalisa Paul \& Aisha Sultana, Pp. 20307-20308

\section{Book Review}

Freshwater fishes of the Arabian Peninsula - Rajeev Raghavan, Pp. 20309-20310

Publisher \& Host

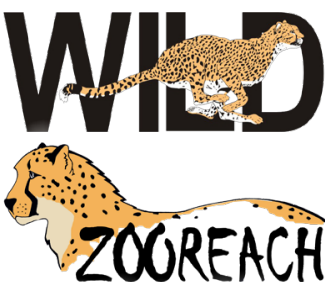

Threatened Taxa 